NBER WORKING PAPER SERIES

\title{
DOES INFORMATION HELP OR HINDER JOB APPLICANTS FROM LESS DEVELOPED COUNTRIES IN ONLINE MARKETS?
}

\author{
Ajay K. Agrawal \\ Nicola Lacetera \\ Elizabeth Lyons \\ Working Paper 18720 \\ http://www.nber.org/papers/w18720 \\ NATIONAL BUREAU OF ECONOMIC RESEARCH \\ 1050 Massachusetts Avenue \\ Cambridge, MA 02138 \\ January 2013
}

We thank Victor Aguirregabiria, Christian Catalini, Avi Goldfarb, Matthew Grennan, John Horton, Mario Macis, and Heather Royer for thoughtful input on earlier drafts. Special thanks to John Horton from oDesk for sharing the data with us, and to Christian Catalini for assistance with the data. Participants at seminars at the 2012 NBER Summer Institute, University of Toronto, Imperial College London, and University of Bologna offered insightful feedback. Alexandra Eremia provided excellent research assistance. We gratefully acknowledge funding support from the Centre for Innovation and Entrepreneurship at the Rotman School of Management, the Martin Prosperity Institute, the Social Sciences and Humanities Research Council of Canada, and the University of Toronto. The views expressed herein are those of the authors and do not necessarily reflect the views of the National Bureau of Economic Research.

NBER working papers are circulated for discussion and comment purposes. They have not been peerreviewed or been subject to the review by the NBER Board of Directors that accompanies official NBER publications.

(C) 2013 by Ajay K. Agrawal, Nicola Lacetera, and Elizabeth Lyons. All rights reserved. Short sections of text, not to exceed two paragraphs, may be quoted without explicit permission provided that full credit, including $(\mathcal{C}$ notice, is given to the source. 
Does Information Help or Hinder Job Applicants from Less Developed Countries in Online Markets?

Ajay K. Agrawal, Nicola Lacetera, and Elizabeth Lyons

NBER Working Paper No. 18720

January 2013

JEL No. F01,J24,J7,O19,O33

\begin{abstract}
Online markets reduce certain transaction costs related to global outsourcing. We focus on the role of verified work experience information in affecting online hiring decisions. Prior research shows that additional information about job applicants may disproportionately help or hinder disadvantaged populations. Using data from a major online contract labor platform, we find that contractors from less developed countries (LDCs) are disadvantaged relative to those from developed countries (DCs) in terms of their likelihood of being hired. However, we also find that although verified experience information increases the likelihood of being hired for all applicants, this effect is disproportionately large for LDC contractors. The LDC experience premium applies to other outcomes as well (wage bids, obtaining an interview, being shortlisted). Moreover, it is stronger for experienced employers, suggesting that learning is required to interpret this information. Finally, other platform tools (e.g., monitoring) partially substitute for the LDC experience premium; this provides additional support for the interpretation that the effect is due to information about experience rather than skills acquired from experience. We discuss implications for the geography of production and public policy.
\end{abstract}

Ajay K. Agrawal

Rotman School of Management

University of Toronto

105 St. George Street

Toronto, ON M5S 3E6

CANADA

and NBER

ajay.agrawal@rotman.utoronto.ca

Nicola Lacetera

University of Toronto

105 St. George Street

Toronto, ON M5S 2E9

Canada

and NBER

nicola.lacetera@utoronto.ca
Elizabeth Lyons

Rotman School of Management

University of Toronto

105 st george street

Toronto, ON

liz.lyons@rotman.utoronto.ca 


\section{INTRODUCTION}

Markets that shift from offline to online often experience a decline in certain transaction costs, such as search, as has been shown in a variety of industries (Autor, 2001; Dellarocas, 2003; Moe \& Fader, 2004; Overby \& Jap, 2009; Terwiesch et al, 2005). In this paper, we examine a market where online platforms are growing rapidly in terms of the volume and scope of transactions: contract labor. ${ }^{1}$ These platforms globalize traditionally local contract labor markets, enabling firms in high-income countries to more easily outsource jobs to contractors in low-income environments. ${ }^{2}$ Thus, these platforms may increase the returns to outsourcing and, more generally, lead to a more efficient organization of economic activity. However, the globalization of labor markets presents not only benefits but also brings into sharp relief certain transaction costs such as those incurred due to the inability to meet face-to-face and address particular informational asymmetries (Autor, 2001; Laubacher \& Malone, 1998).

One way in which these transaction costs may be lowered is through the provision of verified information. Although contract labor platforms do not verify all information, such as prior offline work experience, they do provide verified information about activity that occurs on the site, such as work experience accumulated on the platform. Pallais (2012) shows that even small amounts of verified information, specifically previous work experience on a platform, can dramatically improve employment opportunities as well as wages for contractors. This type of information may influence the relative cost of hiring certain types of contractors. We focus on the difference between contractors applying from less developed countries (LDCs) as opposed to those applying from developed countries (DCs), and on the effect of verified information on the likelihood of recruiting DC versus LDC job applicants.

Specifically, we examine whether verified information about platform-specific work experience helps or hinders LDC relative to DC applicants. The theory and evidence on the effect of information about credentials on hiring decision is ambiguous. On the one hand, this information might further penalize job applicants at an initial disadvantage (e.g., applicants from an LDC) because employers discount the information about individuals in this group, thus giving a further lead to more

\footnotetext{
${ }^{1}$ For instance, Elance went from having 125,000 jobs posted in the first quarter of 2011 to having almost 200,000 posted in the first quarter of 2012 and contractor earnings on the site grew from about $\$ 70$ million in 2009 to almost $\$ 150$ million in 2011 (Elance.com, 2012). Similarly, contractors registered on oDesk earned about $\$ 60$ million in 2009 and this grew to over \$220 million in 2011 (oDesk.com, 2012). According to Horton (2010), workers on online labor markets earned about $\$ 700$ million by 2009 and The Financial Times (2012) reports that these markets combined will be worth $\$ 1$ billion by the end of 2012 .

${ }^{2}$ The top contractor source countries on the largest online contract labor platforms, such as oDesk and Elance, include India, the Philippines, Pakistan, Ukraine (as well as the U.S. and Canada), and the majority of jobs are posted by companies in the U.S., U.K., Canada and Australia.
} 
advantaged contractors (e.g. those from DCs). This is reported in a number of studies, especially in the literature on labor market discrimination (Bertrand \& Mullainathan, 2004; Carlsson \& Rooth, 2007; Lahey, 2008). On the other hand, some studies in this literature show that information on credentials may especially benefit disadvantaged individuals because, at the margin, information has a higher influence on the employer's perception of the applicant, leading to a larger positive update in beliefs (Figlio, 2005; Heckman et al., 2008; Lang \& Manove, 2011; List, 2004; Tilcik, 2011). ${ }^{3}$

We base our empirical analysis on 424,308 applications for 14,733 jobs posted on oDesk, the largest and fastest growing platform for contract labor in the world at the time of writing. First, the data reveal a large LDC penalty. Contractors applying from LDCs have a lower chance of being hired than applicants from DCs (about 25\%). This holds even after we control for most characteristics that employers observe (the ability to observe almost everything that the employer observes is a particularly research-friendly feature of online labor markets), and for job-level unobserved heterogeneity. This finding is particularly striking given the intent of the platform to aggregate and integrate labor markets (Groysberg et al., 2011).

Second, the data indicate that there is an experience benefit; applicants with more platformverified work experience are more likely to be hired. Third, and most central to the objective of this research, we find evidence of an LDC experience premium: the benefit from verified experience information is disproportionately higher for LDC relative to DC applicants. In other words, the LDC penalty is at least in part due to a disproportionate difficulty in evaluating the quality of LDC applicants. The provision of verified information about work experience is therefore particularly valuable for LDC applicants. In the Appendix we propose a simple model to explain this finding, based on a form of statistical discrimination due to different priors on the quality of applicants.

We also find that the LDC experience premium is not driven by a particular type of work (e.g., administrative, website development, writing), but rather is robust across most job categories. Furthermore, the LDC experience premium applies to a variety of outcome measures in addition to our primary outcome (i.e., the probability of hiring a given applicant). In particular, the wage that individuals bid for a job increases with experience for all contractors, but especially so for contractors in LDCs. Similarly, the likelihood of being shortlisted and also of being invited for an interview both increase with platform work experience, again especially so for LDC contractors.

\footnotetext{
${ }^{3}$ Antonji \& Pierret (2001) offer a theoretical basis for this: they suggest that employers with little information about potential hires may statistically discriminate on the basis of race but that the relationship between race and wages should fall as employers accumulate more information about worker productivity.
} 
Our results also suggest that if an employer previously used the platform, then she is more responsive to verified experience information when making hiring decisions, and especially so for LDC applicants. Thus employer learning may be a factor in interpreting this information that concerns prior experience.

Finally, other tools on the platform that reduce the risk of hiring a lower quality contractor diminish the value of verified experience information. In particular, hourly-wage contracts facilitate low cost monitoring through a feature on the platform, but fixed-fee contracts do not. We report that the LDC experience premium is substantially higher for jobs that employ a fixed-fee contract. In other words, the monitoring tool partially substitutes for the provision of verified experience information. Thus, there are multiple channels through which online platforms can flatten the market for contract labor, and verified experience information is only one of them. For example, Ghani et al. (2012) identify online ethnic hiring by Indian-origin employers of contractors in India as another channel; and Stanton and Thomas (2012) report evidence that online employment agencies help contractors overcome the inexperience barrier.

The findings on learning and monitoring also help to distinguish between an "information" interpretation of our main result and a "skills" explanation whereby LDC candidates become disproportionately better with experience. These explanations may be observationally equivalent as they could both lead to a disproportionate impact of experience on the likelihood of hiring an LDC applicant; however, our additional analyses lend support to the former interpretation. For example, the stronger effect for experienced employers is inconsistent with a skills explanation because inexperienced employers should equally value quality. In contrast, it is consistent with the information interpretation; employers learn from experience how to interpret the information. Similarly, the findings on contract type are consistent with the information interpretation but not with the skills explanations. If our main finding was the result of omitted variable bias (e.g., actual applicant quality, instead of an asymmetry in beliefs about quality across the two groups), then we would not expect to find a higher LDC experience premium for fixed price versus hourly contracts.

These results have implications for managers. First, they provide insight into the sensitivity of certain margins in the context of online markets for contract labor. To the extent that verifiable information disproportionately benefits skilled labor from low-income regions, these platforms may significantly increase the returns to outsourcing in general, and in particular to distant (and lowercost) locations. In other words, lower transaction costs due to the provision of verified information may affect both the decision of where to hire a contractor from and, since the cost of contracting may 
be reduced due to the increased feasibility of outsourcing to low-wage countries, may also affect the decision of whether to contract out at all, and thus the boundaries of the firm.

Second, these results provide insight on the possible effects of online platforms for contract labor on the distribution of outcomes. In some settings, online markets increase the skewness of outcomes, leading to a "superstar" effect (Elberse \& Oberholzer-Gee, 2007; Tucker \& Zhang, 2007). Conversely, other studies indicate that under certain conditions online markets tend to reduce the skewness of outcomes, possibly due to differences in search methods and the types of information available (Brynjolfsson et al., 2011; Peltier \& Moreau 2012; Zentner et al., 2012). Our results indicate that the market for contract labor, at least with respect to the effect of providing verified information on job experience, may be of the latter type.

We describe our research setting in Section 2, the data in Section 3, and our empirical design in Section 4. Results are reported and interpreted in Section 5, and Section 6 concludes.

\section{EMPIRICAL SETTING}

We conduct our study using data from oDesk, an online platform designed to facilitate employercontractor matches. The Silicon Valley-based company was founded in 2004 and experienced rapid growth every year since. According to the company, since founding, the cumulative transaction value exceeds US\$225 million, the total number of jobs posted exceeds 1 million, and the total number of contractors that are part of the oDesk network is approaching 1 million. ${ }^{4}$ In terms of the number and value of transactions per year, oDesk is the largest company in its industry, which includes other rapidly growing online market makers for contract labor such as Elance, Guru, and Freelancer. The Financial Times (2012) estimates that the combined transaction volume across these platforms will be about $\$ 1$ billion by the end of 2012 . Overall, these online platforms are similar to each other in terms of their purpose, structure, and business model, although there are some differences in areas such as employer monitoring ability, secondary sources of platform revenue, and the types of employer and contractor information provided.

Employers register on the platform and then post jobs on the site. Contractors register on the platform and then bid for jobs. Bid information includes a proposed fee, cover letter (optional), and profile of the contractor, which includes information such as education, work experience, and location. Employers review bids and may short-list and interview promising bidders prior to making

\footnotetext{
${ }^{4}$ In its first two years of business, oDesk experienced revenue growth of 4,573\% (Deloitte, 2007) and continued to grow at more than $1,000 \%$ per year (Chafkin, 2010). In 2007, total earnings on the site were less than $\$ 20$ million. The same amount was earned in September 2011 alone, with an average pay of $\$ 4,000$ per job. In 2010, contractors earned almost $\$ 120$ million on the site.
} 
a decision and hiring a contractor. The employer may decide against hiring any contractor and cancel their job without penalty. Upon completing a job, the employer pays oDesk the pre-specified project fee and rates the performance of the contractor. The contractor also rates the employer. oDesk pays the contractor and records the job in the contractor's job history. We utilize this latter piece of information as a measure of platform-specific work experience.

Employers classify each job they post as being one of eight types: web development, writing \& translation, administrative support, software development, business services, design \& multimedia, customer service, and networking \& information systems. In addition, the employer provides a description of the job and the skills required to complete it. Also, the employer specifies the nature of the contract: hourly or fixed fee. oDesk adds other information to the posting including the employer's location and their previous activity on oDesk.

Contractors advertise themselves by posting profiles that include information on their education, work history (both on and off the platform), and country of residence. oDesk reports each contractor's entire oDesk work history, including the amount paid for each job, a description of each job and, for completed jobs, employer feedback, on the contractor's profile. In addition, oDesk offers contractors the option to demonstrate their abilities by taking oDesk-administered tests, although posting the results is optional. Although the majority of contractors work independently, some are associated with agencies that employ staffing managers who handle job applications and take a percentage of the contractor fee.

The business model of oDesk's is based primarily on transaction fees. Specifically, the platform does not charge employers for posting jobs, but does charge employers $10 \%$ of the transaction value when a contractor is paid at the end of a job. There are no additional fees charged to contractors.

\section{DATA AND DESCRIPTIVE STATISTICS}

\subsection{Dataset construction}

We collect data on all job postings and applications on oDesk from the month of January, 2012. There were 90,585 jobs posted during this period. Of these, 45,313 were filled (i.e. contractors were hired); only one contractor was hired in 36,921 of the cases, whereas in the remaining 8,392, multiple hires were made (with a range between 2 and 632). We focus on the cases where a single contractor was hired..$^{5}$ Also, we focus on postings for which at least one applicant was from an LDC, at least

\footnotetext{
${ }^{5}$ Direct experience on the platform and conversations with oDesk personnel revealed that jobs for which multiple people are hired may be posted for a number of different reasons. For example, employers may be running "tests" or "trials" in order to then select one single contractor for a subsequent job. Although this is not common, oDesk and
} 
one was from a DC, and the job was posted by a DC entity. Our final sample includes 14,617 job postings and 420,833 job-application observations. ${ }^{6}$

Applicant success (being hired for a given job) is our main outcome variable. We code it as equal to 1 if a contractor is hired and 0 otherwise. We define LDC status using an indicator equal to 1 if a contractor resides in an LDC and 0 otherwise, using the World Bank classification (Countries \& Economies, 2011). We operationalize platform-specific experience using the number of previous job contracts, with an indicator that equals 1 if contractors have more than the sample median number of prior contracts (4) and 0 otherwise. Figure 2 shows the distribution of online experience in our sample. The distribution is highly skewed, with about $75 \%$ of applicants reporting less than 15 previous jobs, and a handful of individuals reporting 100 or more previous tasks completed. The distribution of offline job experience is even more skewed, with the $75^{\text {th }}$ percentile being 2 jobs, and a few cases of 50 or more jobs (the max is 94). Thus, we use indicator variables for job experience since these data are so skewed. However, in the Appendix, we report analyses with alternative, more continuous (but still categorical) measures of online experience and our main findings persist.

For each observation, we observe a wealth of information from all applicants' profiles, corresponding to almost everything that market participants observe. As further discussed in Section 4 below, this is a particularly research-friendly feature of the data that allows us to control for almost all available information, leaving very limited concerns for omitted-variable issues in the regression analysis. Specifically, we observe contractors' education, work history (both on and off oDesk), test scores, oDesk feedback rating, agency membership, country of residence, oDesk advertised wage, wage bid for a given job, previous jobs held on the platform, whether they have a profile picture, whether they were shortlisted and/or interviewed for the job, and whether or not they were previously hired by the employer who posted the focal job. We also collect summary information on the application letter; specifically, we have a measure of how original the content of a letter is, relative to an "automated" form letter. Sending a form letter often reflects scarce interest in a job. In our

other platforms may also be used by researchers to run experiments, where typically multiple people are hired for one job. The motivations for posting and filling these jobs (and possibly for applying for these jobs) are potentially very different than what we normally associate with employer motivation for hiring in ways that would add noise to our data. For these reasons, we limit our sample to jobs for which only one applicant was hired.

${ }^{6}$ In the Appendix, we compare job characteristics between jobs that were dropped from and those included in our final sample. In particular, we compare our final sample to: (1) the sample of jobs with multiple hires (and both DC and LDC applicants); and (2) the sample of jobs with 1 hire and either only DC or LDC applicants. Although minor differences exist between the three groups, they look similar along most characteristics, particularly when comparing the sample used in this paper and the sample of jobs with only LDC or DC applicants, and the differences that do exist between our sample and the multiple hires seem largely due to more hires being made in the latter sample. Note also that our main regression results are robust to including the sample of jobs with multiple hires (Table A6). 
analyses below, we find that a higher share of original content does indeed correspond to higher hiring probability. Finally, we have information on whether the application was initiated by the employer or the contractor and on job and employer characteristics. Table 1 reports a description of all variables and how we construct each.

\subsection{Descriptive statistics}

Table 2 reports summary statistics on our sample of contractors (more specifically, contractorsapplications), and Table 3 reports statistics on our sample of jobs and employers. A large majority of the contractors in the sample $(364,921$ or almost $87 \%)$ are from LDCs, and the average share of applications by LDC contractors for a given job is $77.7 \%$. However, LDC contractors are only hired for $66.5 \%$ of the jobs. ${ }^{7}$ Of course, this disproportionately low rate of hiring LDC contractors may be explained by differences in quality between LDC and DC contractors or by differences in the types of jobs they apply for. We address these issues in the regression analyses to follow. Foreshadowing that analysis, the descriptive evidence in the last two columns of Table 2, where we report contractor characteristics, suggests that LDC and DC contractors are similar on many dimensions.

Some differences, however, are worth noting: LDC contractors are slightly more educated than DC contractors and they are also more than twice as likely to be members of employment agencies. Contractors from DCs have higher test percentages on average than contractors from LDCs but, given that contractors can delete scores, it is unclear whether this difference is because DC contractors do better on tests or because they are more likely to delete bad test scores from their profiles. In addition, DC contractors have much higher average advertised wages and wage bids than contractors from LDCs. LDC contractors are less than half as likely as DC contractors to be invited to apply for a job by the employer and much less likely to have been hired by the employer in the past. Finally, LDC contractors appear to write less original cover letters than DC contractors. In summary, although there are some differences between the sample of DC and LDC contractors, these differences do not appear to reflect clear differences in ability or quality. ${ }^{8}$

The raw data also suggest that experience on the platform, although similar on average between LDC and DC applicants, provides differential benefits in terms of likelihood of being hired. This likelihood is positively correlated with work experience on oDesk for both LDC and DC contractors.

\footnotetext{
${ }^{7}$ A regression on whether a contractor from an LDC is hired for a job on the share of applicants from LDCs for that job, with one observation per job and the constant set at zero, estimates a slope of 0.89 , significantly below 1 .

${ }^{8}$ A Blinder-Oaxaca type of decomposition of the likelihood of being hired shows that of the 6.35 percentage points of difference in the likelihood of being hired for DC and LDC applicants (9.08\%-2.71\%), only about 6.4 percentage points can be attributed to the (observable) characteristics of the applicants.
} 
However, in relative terms, LDC contractors benefit more from oDesk experience. Specifically, DC contractors with experience below or equal to the sample median of 4 previous jobs are about 4 times more likely to be hired than LDC contractors in the same experience group (0.067 vs. 0.017), whereas the ratio declines to about 3:1 for more experience applicants (0.114 vs. 0.037); the hiring chances thus increase more than twofold for LDC contractors with above-median experience, as opposed to a $60 \%$ increase for DC applicants. Therefore, although a gap in hiring chances between LDC and DC workers remains, having more experience on the platform appears disproportionately beneficial for LDC applicants.

We illustrate the large impact of oDesk experience for LDC applicants in Figure 3: here we report, together with the average share of LDC applications per job, the share of LDC applicants that were hired overall, the share of LDC applicants with low experience that were hired out of all those with low experience that were hired, and the share of LDC applicants with high experience that were hired out of all those with high experience that were hired. The figure shows a substantial difference in the likelihood that a hired applicant is from an LDC, in the subgroups of high-experience and lowexperience hired workers. The raw data is therefore suggestive of DC employers' reluctance to hire from LDCs (note also that the raw likelihood of being hired for DC freelancers with no previous experience on oDesk is similar to that of an LDC with online experience in the top quartile of the distribution); and the relative benefits to LDC contractors from building a reputation by accumulating experience on the platform.

These results are consistent with the following interpretation, based on a form of statistical discrimination due to different priors on the quality of applicants. Previous job experience appears to represent a positive signal that increases the likelihood of being hired, with the updating on quality being stronger for applicants who are at an initial disadvantage in terms of employers having a lower prior about their ability and/or higher uncertainty around this prior. This applies only for experience on the platform because it is comparable among workers from different origins, and is also a signal of ability on the job because having platform experience also implies having won a contract over competitors for a given job. In the Appendix, we propose a simple formalization of this view.

Interestingly, the descriptive statistics on wage bids display a similar pattern: the increase in the natural log of wage bids for LDC applicants with and without above-median experience is 0.32 , as opposed to 0.24 for DC applicants. The fact that it might take a relatively short period of time to accumulate this experience suggests that the effect is more likely due to the reliability of this verified information, rather than due to the acquisition of skills from the experience. We address this issue 
more formally in the empirical section. We now proceed to regression analysis to test the robustness of these basic descriptive findings and their interpretation.

\section{EMPIRICAL STRATEGY}

To address our main research question - does verified information on work experience disproportionately benefit LDC applicants? - we must consider a few identification concerns. First, employers may be less likely to hire contractors from LDCs because they are of lower quality rather than because of their country of residence. Similarly, employers may be more likely to hire contractors with high oDesk experience because these contractors have other qualities that are valued by employers. However, unlike in labor markets where employers and applicants are able to meet in person and learn more about each other in ways that are unobservable to the researcher, the variables that we observe, and that we described in the previous section, represent virtually all the information available to employers about applicants. Thus, controlling for these variables in a regression framework considerably allays omitted-variables concerns.

What we do not observe are private interactions (offline or not mediated/recorded by oDesk) between applicants and employers. Through these interactions, job posting entities may extract further information on the quality and fit of applicants, potentially related to their origins as well as their experience level or other observables. From direct experience with hiring on the site, personal interactions initiated by applicants are minimal and do not provide much information about contractor quality beyond what is already provided in profile pages. Moreover, some variables in our dataset could be more directly correlated with the likelihood of informal interaction, before or during the job posting and hiring process. For example, in some cases, as mentioned above, employers invite particular contractors to apply for jobs. Also, there are instances where the pool of applicants includes some contractors who already worked for the same employer in the past. The analyses reported below are robust to excluding jobs (and all applicants for those jobs) where any of these two indicators is positive for at least one applicant (Table A7). Another source of information that we do not observe and that is potentially related to the origin and other characteristics of the applicants is the exact content of cover letters that applicants sent with their application. If, for example, applicants from LDCs or with lower experience are worse at writing cover letters, then this might indicate lower quality. Again, as mentioned above, we rely on a proxy for the content of the cover letter, as given by the share of "original" content in the letter.

Second, we account for potential differences across job and employer characteristics by using a regression model that conditions on job-employer characteristics. We model the effect of our 
covariates on the likelihood of being hired through a conditional fixed-effect logit model (McFadden, 1974), where we group the data by job posting (or employer-job posting), and the alternative set for each job posting includes the applicants to that job. More specifically, we treat each application as a separate observation even though some contractors apply for more than one job in our sample (Of the 420,833 job-application observations, we have 75,972 unique contractor observations). ${ }^{9}$ This framework is appropriate in our setting for several reasons. First, employers can only hire from the contractors who apply for their job and we require employer choice sets to reflect this restriction. Second, it is likely that employers consider all their options when choosing whether or not to hire a contractor so that each hiring decision is conditional on all other applicant characteristics. Third, this model also explicitly assumes that each employer hires the applicant who maximizes her own utility. Fourth, we calculate the likelihood of being hired in this model relative to each job (McFadden, 1974; Cameron \& Trivedi, 2009).

More formally, let $A_{j}$ represent the set of $k$ applicants for job $j$, let $Y_{i j}$ be an indicator for whether applicant $i$ is hired. Each employer maximizes her utility according to the characteristics of alternatives: $U_{i j}=\alpha+X_{i} \beta+\varepsilon_{i j}$, where $X_{i}$ is a vector of applicant characteristics, $\beta$ is a vector of parameters, and $\varepsilon_{i j}$ is the logit error term (type I extreme value). Therefore, the conditional probability that applicant $i$ is hired out of $A_{j}$ applicants is:

$P\left(Y_{i}=1 \mid \sum_{h \in A_{j}} Y_{h}\right)=\frac{e^{X_{i} \beta}}{\sum_{h \in A_{j}} e^{X_{h} \beta}}$,

where $\beta$ is a vector of parameters to be estimated through maximum likelihood. ${ }^{10,11}$ Our main regressors of interest are an indicator for whether an applicant is from an LDC, and measures of previous job experience.

\footnotetext{
${ }^{9}$ We treat each application as a separate observation even though some contractors apply for more than one job in our sample. We could, in principle, run analyses with individual fixed effects. However, within individuals there is no variation in LDC status, and only for a handful of applicants does the online job experience, our other main variable of interest, move from low to high in the one month of data that we have. In addition, focusing only on those individuals with multiple applications and variation in the experience indicator would censor the sample as the employers would be modeled as choosing an applicant out of a subsample of all applicants for that job. Individual fixed effects would be a way to deal with remaining variation that the employers could observe and the researcher could not; however, given the types of interactions online as explained above, the detailed information we have on each applicant for a job, and the additional robustness tests we describe below, we believe that our empirical strategy addresses the possibility of biases from selection or omitted variables.

${ }^{10}$ Note that $\sum_{h \in A_{j}} Y_{h}=1$ for each job, because there is only one hire per job in our case. The results are very similar with alternative discrete choice specifications, such as alternative-specific conditional logit as well as mixed logit models with observations grouped at the job-employer level. Alternative-specific conditional logit allow for a separate constant to be estimated for each alternative (the conditional logit model we use here is equivalent to an alternative-specific conditional logit where the constant terms are constrained to be the same). Mixed Logit (or random-coefficients) models allow for coefficients to vary across groups, and also overcome a common limit of
} 
Third, besides the potential for omitted variables bias (at the individual applicant or job posting level), our estimates may also suffer from selection bias. In particular, we may be concerned that more experienced contractors are better at applying for jobs for which they are likelier to be hired. Because contractor ability to apply for the "right" jobs should not vary with employer characteristics, provided that applicant characteristics do not differ across these employer characteristics, we reject this interpretation of contractor learning below by showing that online experience premiums vary with employer experience on oDesk whereas applicant characteristics do not.

We also provide analyses with alternative outcome variables as well as additional cuts of the data to corroborate our main findings.

\section{RESULTS}

We structure our analysis in three steps, each based on estimating a specification of Equation (1). First, we estimate the LDC penalty, the platform-specific experience benefit, and the LDC experience premium. The penalty, the discount that the average employer applies to applicants from LDCs, is reflected in a lower probability of hiring a contractor from an LDC compared to a DC after controlling for observable characteristics such as education and off-platform experience. The platform-specific experience benefit is the average increase in probability of hiring an applicant that has accumulated work experience on the platform compared to one that has not. The LDC experience premium is the extent to which LDC applicants experience a disproportionate benefit from accumulating platform-specific experience. We examine each of these three relationships in the context of our main outcome measure (likelihood of being hired) and then estimate them using two earlier-stage outcome measures (attaining an interview and being short-listed) as well as with another key measure: wages.

choice models given by the independence of irrelevant alternatives. The point estimates we obtained from mixed models are almost identical to the conditional logit estimates.

${ }^{11}$ A potential alternative specification would be to use a linear probability model with job-level fixed effects. This would make the interpretation of the estimated coefficients more immediate. However, there would be some important limitations and concerns. First, and related to the advantages of a conditional logit framework, a linear probability model would not reflect the choice structure embedded in the hiring problem. In addition, in order for all applicant characteristics to be considered in each individual hiring decision, we would have to make strong assumptions about how these characteristics enter into the employer's choice problem to be able to control for them. One alternative would be to control for all applicant characteristics in each individual decision, but this would be very difficult, particularly with jobs that have many applicants. Finally, in a linear fixed-effect model there would be an inherent correlation in the error terms due to the fact that for each job posting one and only one hire is possible (and observed). In any event, linear probability models convey very similar estimated marginal effects. The logit coefficient estimates, and in particular the coefficient on the main interaction term of interest, has an immediate interpretation in terms of multiplicative effect. 
Second, we show that the LDC experience premium is reasonably robust across job types (e.g., administration, web development, and writing). We also report evidence that suggests interpreting the information associated with platform-specific experience might require some investment in learning to use the platform; we find that the LDC experience premium is larger for employers with more hiring experience on the platform.

Finally, we report findings suggesting that the LDC experience premium is greater under conditions that are less conducive to monitoring (fixed-fee versus hourly contracts). In addition to providing further insight on the characteristics of the LDC experience premium (concerning learning and monitoring), the latter two results also provide further evidence that supports the causal interpretation we advance here concerning how verified information about experience increases the probability of being hired.

\subsection{Main analyses: Likelihood of being hired for a job}

We begin by estimating the LDC penalty (Table 4). The first specification is a pooled logit with standard errors clustered at the job level, with no control variables. We then add controls and employer-job fixed effects. The penalty is large and statistically significant in all specifications. In the uncontrolled logit specification (column 1) the estimated LDC penalty is very large: the probability of an LDC applicant being hired is less than a third than that of a DC applicant. When we add controls (column 2) the coefficient estimate on the LDC indicator increases (odds ratio from 0.31 to 0.56), indicating that part of the LDC penalty is explained by observable quality differences between LDC and DC applicants. A conditional fixed-effect model (column 3) estimates a further reduced gap, indicating that there are probably also differences in jobs and employers that affect the likelihood of a an employer (typically from a DC) hiring an applicant from an LDC. These differences can include the quality of matching jobs with applicants, which may be related to the origin of the applicant. Still, even after controlling for alternative-specific covariates and employerjob heterogeneity, the odds that an LDC contractor is hired are estimated to be only slightly above half that of a DC contractor. Interestingly, these values are similar to those found in studies of the likelihood of hiring or call-backs for minorities (especially African Americans) compared to Caucasians (Bertrand and Mulhainathan, 2004; Pager, Western and Bonikowski, 2009).

Next, we turn to our estimates of the platform-specific experience benefit. In the same three specifications as above (Table 4) we find that, on average, applicants benefit significantly, in terms of the probability of being hired, from work experience on the platform (column 1). The estimated coefficient on the indicator for platform-specific experience decreases when controls are added 
(column 2) but increases slightly when job fixed effects are included (column 3). Overall, when we include controls and fixed effects, the estimate indicates that having above-median experience on the platform increases the likelihood of being hired by 1.6 times.

The estimates on the control variables, with the exception of offline work experience, are statistically significant (Appendix Table A4), perhaps not surprisingly given the large sample size; however, most of the estimates are small in magnitude. The estimates worth noting because of their size are the fraction of originality in applicants' cover letters, employer initiated applications, and the indicator for whether a contractor was previously hired by an employer. These are all positive.

We then move to our primary phenomenon of interest - the LDC experience premium. We do this by interacting the LDC indicator with the oDesk experience indicator (Table 5). The estimated coefficients suggest that LDC contractors benefit disproportionately from above-median platform experience compared to DC contractors. The unconditional hiring ratio for low experience LDC contractors is $1.6 \%$ compared to $6.7 \%$ for low experience DC contractors. Therefore, the estimates (in odds ratios) imply that the predicted probability of a DC contractor being hired increases due to experience by a factor of 1.233 (to 8.3\%), whereas for LDC applicants, the multiplicative factor is $1.233 * 1.413=1.742$ (increasing the estimated likelihood to $2.8 \%$ ).

In Appendix Table A8, we experiment with more fine-grained categorizations of the platform experience variable, by splitting the sample by quintiles of experience level. The main findings persist. At the top end of the distribution, 19 or more previous jobs, DC contractors are estimated 2.5 times as likely to be hired as LDC contractors. However, for inexperienced applicants this ratio is much higher (4.2:1, see also figure 3). Even still, inexperienced DC applicants are more likely to be hired than highly experienced LDC applicants. Nonetheless, platform-specific experience significantly reduces the gap. In fact, it appears that the median level of experience is somewhat of a "turning point" in terms of the increase in relative benefit from platform-specific experience for LDC contractors. Note that the median level of platform-specific experience is relatively low and given the average length of a contracted job can be accumulated in a short amount of time.

The findings also resonate with the evidence on discrimination in "offline" labor (and other) markets that shows that the availability of more information disproportionately improves labor market prospects for disadvantaged populations (Figlio, 2005; Heckman et al., 2008; Lang \& Manove, 2011; List, 2004; Tilcik, 2011). In our setting, it is remarkable how little experience is required to significantly increase contractor success, especially for contractors who are at an initial disadvantage. This suggests an important role for platform-mediated information in global online labor markets. 


\subsection{Robustness of Main Result}

\subsubsection{Job Types}

To ensure that our main findings are not driven by one particular type of job, we perform a similar analysis to that reported in Table 5, but separately for each job category. We restrict the analysis to job types with at least 500 posted jobs and thus consider the following categories: administrative, web development, writing, software development, and marketing (Table 6). Our results indicate that the LDC experience premium persists for almost all job categories. One exception is software development. In this case, platform specific experience benefits all contractors equally.

\subsubsection{Wage bids}

To the extent that information about experience disproportionately benefits contractors at an initial disadvantage, then wage bids should increase more with experience for LDC than DC contractors. ${ }^{12}$ We do find evidence of this. In Table 7, we report the parameter estimates of this log-linear model: ${ }^{13}$ $\ln \left(\right.$ wage $\left._{i j}\right)=\alpha+\beta_{1} L D C_{i}+\beta_{2}$ Experience $_{i}+\beta_{3} L D C_{i} *$ Experience $_{i}+\gamma^{\prime} X_{i j}+\eta_{j}+\varepsilon_{i j}$

where wage $_{i j}$ is the wage bid by contractor $i$ applying for job $j$. Because bids have a different meaning for hourly and fixed contracts, we perform our analyses separately for these two types of contracts. The other variables are as described in Model (1) above, and $\eta_{j}$ represents fixed effects at the job-employer level (standard errors are clustered at the same level as the fixed effects). An alternative specification that would get closer to giving us causal estimates would include individual fixed effects, exploiting the fact that some individuals apply for multiple jobs over the period of interest. However, there is very little within-individual variation in our main variables; the LDC indicator is invariant across observations for the same individual by construction and the experience indicators do not vary because of the relatively short time span covered by the data. Therefore, the evidence presented here should be taken as mostly descriptive, though informative.

\footnotetext{
${ }^{12}$ In general we expect lower wages for LDCs due to the lower cost of living; however we do not expect contractor experience to have a differential impact unless information about experience disproportionately affects prior beliefs. A Blinder-Oaxaca decomposition of the log of wage bids reveals that, of the about 0.70 difference in the natural $\operatorname{logs}$ of wage bids between DC and LDC employers, only 0.005 (for hourly jobs) and 0.015 (for fixed price jobs) is attributed to differences in (observable) individual characteristics.

${ }^{13}$ Comparisons of scale-corrected R-squared and sum of squared residuals (based on a normalized Box-Cox transformation, which is necessary to compare two models where the dependent variable in one of them is a nonlinear transformation of the other) show that the log-linear specification is a significantly better fit that a linear specification for wage - indeed the wage level is highly skewed, making linear regressions less reliable. The Rsquared from these corrected regressions about 2.5 times higher both for the hourly and fixed-price contract subsamples, and the chi-squared test for the better fit of the log specification [(N/2)* $\ln ($ higher SSR/lower SSR)] is highly significant.
} 
The estimates show significantly lower wage offers (by about exp(-.502)-1=-39\%, from column 3) for inexperienced LDC workers as opposed to inexperienced DC workers bidding on hourly wage jobs; however, the increase in wage offers by LDC contractors is about $65 \%$ higher than the increase for DC contractors (15.6\% increase vs. 9.3\%). Similar results hold for fixed price bids, with stronger effects for these jobs. This is consistent with the difference in employers' ability to monitor contractors under the two contract types and suggests that when monitoring is more costly, verifiable information about the applicant becomes even more valuable. We also limit the sample to bids by the winning contractors. These bids can be taken as better proxies for the "equilibrium wage" for that particular job, thus they should be more reactive to valuable information. Estimates are similar to the full sample, especially for fixed price jobs.

\subsubsection{Interviews and Short-listing}

Two optional steps that an employer may take when considering an applicant for a job include interviewing and short-listing. As we display in Tables 2 and 3,11\% of contractors are interviewed and those from DCs are much more likely to be interviewed than those from LDCs; on average, about 3 interviews are performed per job. Short listing is less common; only $3.8 \%$ of contractors in our sample were short listed and DC applicants are more likely than LDC applicants to be short listed (5 out of 100 versus 3.6 out of 100). Using an indicator for being interviewed or short listed as dependent variables in Model (1), we estimate the LDC experience premium and report the estimated coefficients in Table A5. The main result concerning the LDC experience premium persists with both upstream measures of success in the recruiting process.

\subsection{Employer Learning}

Do employers learn to interpret information about platform-specific experience, or is the value of this information immediately obvious? The answer to this question is important for two reasons. First, it provides insight into platform recruiting dynamics. Learning implies that employer recruiting patterns evolve with experience, potentially shifting from hiring DC to LDC contractors. Second, evidence of employer learning reduces identification concerns. In particular, if the LDC experience premium were either the result of contractors improving their quality due to the work experience or improving their ability to apply for jobs (e.g., better cover letters or more effective pricing) due to experience, then we would not expect to see variation across differing levels of employer experience. However, it is plausible that employers learn to evaluate platform-based information, such as prior 
contractor experience on oDesk, as they themselves gain experience on the site. ${ }^{14}$ Indeed, using data from a different online platform for contract labour (Freelancer.com), Mill (2011) finds that employers are more likely to hire contactors from a particular country if they have had a positive experience doing so in the past.

We run the main analyses, as those in Table 5, but split the sample into two groups (Table 8): 1) employers with no experience hiring on oDesk as of January 2012, and 2) employers with prior hiring experience. We also show the main result is robust to splitting the sample at the median level of employer experience. The estimates suggest that, regardless of hiring experience, employers are less likely to hire LDC contractors, but that employers with at least some previous experience appear to value online experience more and, most notably, apply a greater LDC experience premium. We also show that the applicants who apply for jobs posted by experienced versus inexperienced employers have virtually identical characteristics (Appendix, Table A3). Thus, these results suggest that the premium is a result of employer preferences and not contractors' application decisions.

\subsection{Monitoring}

The platform provides employers with two types of contracts that they can use to engage contractors: hourly or fixed fee. The contract type influences the ease of monitoring. Under hourly contracts, contractors complete their work in a virtual "team room" where employers are able to monitor their output by way of screen shots in 10 minute increments. ${ }^{15}$ The trade off for this level of monitoring is that employers are obligated to pay contractors for their time regardless of the quality of work. In contrast, under fixed fee contracts employers do not have easy access to monitor contractors as they work, but employers are able to withhold payment if they deem that the output is of poor quality. ${ }^{16}$ In other words, employers are protected from poor quality work through low cost monitoring in the case of hourly contracts and through optional payment in the case of fixed fee contracts. Contractors are protected from employer reneging through guaranteed payment in the case of hourly contracts and employer evaluations in the case of fixed fee contracts. ${ }^{17}$

\footnotetext{
${ }^{14}$ A number of papers have used experience as a proxy for "sophistication" or ability to process certain signals in markets. See for example Altonji and Pierret (2001) and List (2003).

${ }^{15}$ oDesk takes screenshots of the work of contractors logged into team rooms every 10 minutes so that employers can observe contractors' progress.

${ }^{16}$ Employers have the opportunities to not pay the fixed price if they are unsatisfied with the job. However, this happens very rarely, most likely because of reputational concerns (not paying for a job might lead contractors to post bad reviews about a given employer).

${ }^{17}$ Contractors can penalize employers for unfairly withholding payment in fixed fee jobs by giving them a poor rating, potentially deterring strong applicants from applying to subsequent jobs posted by that employer.
} 
To the extent the LDC experience premium is due to verified information rather than better quality, as we posit, then it should be greater for jobs done under a fixed fee contract compared to those done under an hourly contract since the employer is less dependent on this type of information in the latter case due to their ability to monitor. We examine this by splitting the sample by contract type, and report our results in Table 9. As expected, the LDC experience premium is significantly higher for jobs conducted under fixed fee contracts.

This result is interesting for two reasons. First, it provides further insight into recruiting behavior in the online platform context. Tools that lower the cost of monitoring may disproportionately benefit disadvantaged populations; to some extent they may substitute for other tools that have a similar effect, such as the verified information about prior experience on oDesk that is the central focus of this study. Second, this result provides further evidence that is consistent with our causal interpretation. We would not expect to see such a difference in the estimated LDC experience premium if it were driven by either better quality applications or better quality applicants. Although still not conclusive, the evidence we report here is broadly consistent with our interpretation that the LDC experience premium is due to LDC contractors benefiting disproportionately from verified information concerning prior employment.

\section{DISCUSSION AND CONCLUSION}

We report evidence of an LDC experience premium: LDC contractors benefit more than their DC counterparts, in percentage terms, from verified information indicating prior work experience on the platform. The premium is present across multiple outcomes: likelihood of being hired, wage, likelihood of obtaining an interview, and likelihood of being shortlisted; it is also present across most job types. We interpret these findings as indicating that these platforms facilitate verifiable quality signals that help prospective employers reduce information asymmetries associated with the quality of contractors, particularly those coming from LDCs. Reducing these asymmetries could have important implications for increasing outsourcing efficiency. This may be of particular importance for small firms that have difficulty arranging outsourcing agreements in the absence of such easily available information. Rather than avoiding services (including high-skill) from certain countries, firms may increase the value they derive from online labor by being better able to evaluate the quality of foreign applicants.

Of course we must exercise caution generalizing from our results, which are based on data from a single platform, to all online platforms. Each platform has its own idiosyncrasies. However, most

online platforms provide similar verified information since that is both easy to do and appears to 
have become an industry standard. Thus, although we have no reason to expect the LDC experience premium to be absent from other platforms, we note this as a possibility.

With respect to the broader issue of employee reputation, our study contributes to the growing literature on international labor markets and the relationship between employee reputation and labor market success (e.g., Banerjee \& Duflo, 2000) and with literature that highlights the importance of reputation in online markets (e.g., Dewan \& Hsu, 2004; Jin \& Kato, 2006; Resnick et al., 2006). Specifically, given the importance of verified information about prior experience on oDesk for LDC contractors, such information appears to act as a certification mechanism for contractor abilities. This mechanism is of particular importance when other signals of ability are difficult to interpret (perhaps due to a lack of familiarity with foreign education institutions and employers).

Our results also suggest that, in the case of online markets for contract labor, this information benefits disadvantaged groups relatively more. This is consistent with some prior literature (e.g. Heckman et al., 2008) and inconsistent with other findings (e.g. Bertrand \& Mullainathan, 2004). In addition, the results presented in this paper are consistent with the evidence in Oreopoulos (2011), which shows that skilled immigrants from LDCs are less likely to be hired in Canada than comparable DC workers. Oreopoulos' findings suggest that this could be because employers have trouble inferring worker abilities from experience accumulated in LDCs. Our paper is consistent with this interpretation and, further, implies that this uncertainty over LDC contractors is present even in markets where the majority of the participants are from LDCs. Moreover, our research suggests that this barrier to employment for contractors from LDCs may be at least partially overcome through the use of third party verification (in this case provided "automatically" by the platform).

This research also contributes to the growing stream of literature on skewness in online markets (e.g. Elberse \& Oberholzer-Gee, 2007; Brynjolfsson et al, 2011) and suggests that the information provided by online markets for contract labor may reduce the skew of contractor outcomes under certain conditions.

Finally, our results have implications for labor market policy, particularly as national borders decreasingly restrict the flows of labour and services. Our estimates suggest that facilitating a reduction in employer uncertainty over non-local experience (e.g., internationally recognized skills certification body) may reduce transaction costs, encouraging more competition from LDC workers, and thus reduce DC wages. 


\section{REFERENCES}

Altonji, J.G \& Pierret, C.R. 2001. Employer Learning and Statistical Discrimination. The Quarterly Journal of Economics, 116: 313-350.

Autor, D. H. 2001. Wiring the Labor Market. The Journal of Economic Perspectives, 15: 25-40.

Banerjee, A. V. \& Duflo, E. 2000. Reputation Effects and the Limits of Contracting: A Study of the Indian Software Industry. The Quarterly Journal of Economics, 115: 989-1017.

Bertrand, M. \& Mullainathan, S. 2003. Are Emily and Greg More Employable than Lakisha and Jamal? A Field Experiment on Labor Market Discrimination. American Economic Review, 94: 991-1013.

Brynjolffson E., Hu, Y. J. \& Simester, D. 2011. Goodbye Pareto Principle, Hellow Long Tail The Effect of Search Costs on the Concentration of Product Sales. Management Science, 57: 1373-1386.

Chafkin, M. 2010. The Case, and the Plan, for the Virtual Company. Inc.com.

Cameron, A. C. \& Trivedi, K. P. 2009. Microeconometrics Using Stata. College Station: Stata Press.

Carlsson, M. \& Rooth, D. 2007. Evidence of Ethnic Discrimination in the Swedish Labor Market Using Experimental Data. Labour Economics, 14: 716-729.

Dellarocas, C. 2003. The Digitization of Word of Mouth: Promise and Challenges of Online Feedback Mechanisms. Management Science, 49: 1407-1424.

Deloitte. 2007. 2007 Technology Fast 500: Annual list of the fastest growing companies in North America. 2007: 7.

Dewan, S. \& Hsu, V. 2004. Adverse Selection in Electronic Markets: Evidence from Online Stamp Auctions. Journal of Industrial Economics, 52: 497-517.

Elance.com 2012. www.elance.com.

Elberse A. \& Oberholzer-Gee, F. 2007. Superstars and Underdogs: An Examination of the Long Tail Phenomenon in Video Sales. Marketing Science, 25: 638-661.

Figlio, D. N. 2005. Names, Expectations and the Black-White Test Score Gap. NBER Working Paper, 11195

Financial Times 2012. Virtual Working Takes off in Ems. blogs.ft.com.

Ghani, E., Kerr, W. R. \& Stanton, C.T. 2012. Diasporas and Outsourcing: Evidence from oDesk and India. NBER Working Paper, 18474.

Government of India Ministry of Labour and Employment, 2011. Minimum Wages.

Groysberg B., Thomas, D.A. \& Tydlaska, J. 2011. oDesk: Changing How the World Works. Harvard Business School Organizational Behavior Unit Case, 411-078.

Horton, J. 2010. Online Labor Markets. Internet and Network Economics, 6484: 515-522.

Heckman, J. J. Lochner L. J. \& Todd P. E. 2008. Earnings Functions and Rates of Return. Journal of Human Capital, vol. 2: 1-31.

Jin, G Z \& Kato A. 2006. Price, Quality and Reputation: Evidence from An Online Field Experiment. The RAND Journal of Economics, 37: 983-1005.

Lahey, J. 2008. Age, Women and Hiring. Journal of Human Resources, 43: 30-56.

Lang, K. \& Manove, M. 2011. Education and Labor-Market Discrimination. American Economic Review, 101: 1467-1496.

List, J.A. 2003: Does Market Experience Eliminate Market Anomalies? The Quarterly Journal of Economics, 118 : 41-71.

List, J. A. 2004. The Nature and Extent of Discrimination in the Marketplace: Evidence from the Field. The Quarterly Journal of Economics, 119: 49-89.

Laubacher, R. \& Malone, T. W. 1998. The Dawn of the Elance Economy. Harvard Business Review, Sept-Oct 1998.

McFadden, D. 1974. Conditional Logit Analysis of Qualitative Choice Behavior. In P. Zarembka (ed.), Frontiers in Econometrics; 105-142. New York: Academic Press.

Mill, R. 2011. Hiring and Learning in Online Global Labor Markets. Working Paper.

Moe, W. W. \& Fader, P. S. 2004. Dynamic Conversion Behavior at E-Commerce Sites. Management Science, 50: 326-335.

oDesk 2011. www.odesk.com.

Oreopoulos, P. 2011. Why Do Skilled Immigrants Struggle in the Labour Market? A Field Experiment with Six Thousand Resumes. American Economic Journal: Economic Policy, 3: 148-171.

Overby, E. \& Jap, S. 2009. Electronic and Physical Market Channels: A Multiyear Investigation in a Market for Products of Uncertain Quality. Management Science, 55: 940-957.

Pager, D., Western, B. \& Bonikowski, B. 2009. Discrimination in a Low-Wage Labor Market: A Field Experiment. 
American Sociological Review, 74: 777-799.

Pallais, A. 2012. Inefficient Hiring in Entry-Level Labor Markets. Working Paper.

Peltier, S. \& Moreau, F. 2012. Internet and the 'Long Tail Versus Superstar Effect' Debate: Evidence from the French Book Market. Applied Economic Letters, 19: 711-715.

Philippines Department of Labor \& Employment, 2011. Labor Code of the Philippines.

Resnick, P., Zeckhauser, R., Swanson, J. \& Lockwood, K. 2006. The Value of Reputation on eBay: A Controlled Experiment. Experimental Economics, 9: 79-101.

Stanton, T. \& Thomas, C. 2012. Landing the First Job: The Value of Intermediaries in Online Hiring. Working Paper.

Terwiesch, C., Savin, S. \& Hann, I. 2005. Online Haggling at a Name-Your-Own-Price Retailer: Theory and Application. Management Science, 51: 339-351.

Tilcsik, A. 2011. Price and Prejudice: Employment Discrimination Against Openly Gay Men in the United States. American Journal of Sociology, 117: 586-626.

The World Bank Group. 2010. Data: Countries and Economies 2011.

Tucker, C. \& Zhang, J. 2007. "Long Tail or Steep Tail? A Field Investigation into How Online Popularity Information Affects the Distribution of Customer Choices. MIT Sloan School of Management Working Paper, 4655-07.

United States Department of Labor. 2010. Fair Labor Standards Act Advisor.

Zentner, A., Smith, M. D. \& Kaya, C. 2012. Bricks, Clicks, Blockbusters, and Long Tails: How Video Rental Patterns Change as Consumers Move Online. Working Paper. 
Figure 1: Sample Distribution of Platform Experience

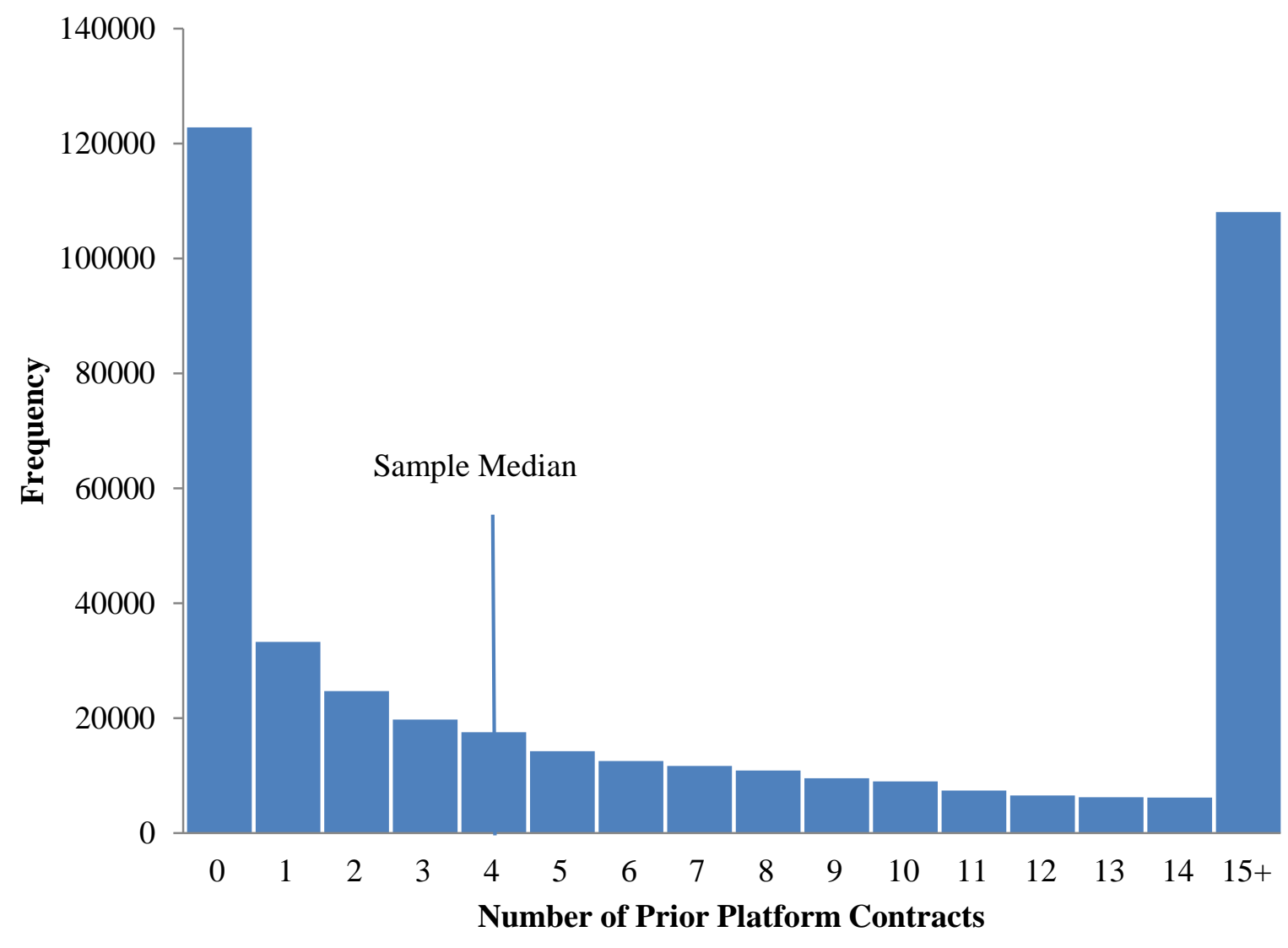


Figure 2: Likelihood of being hired for a job for LDC applicants, overall and by level of platform experience

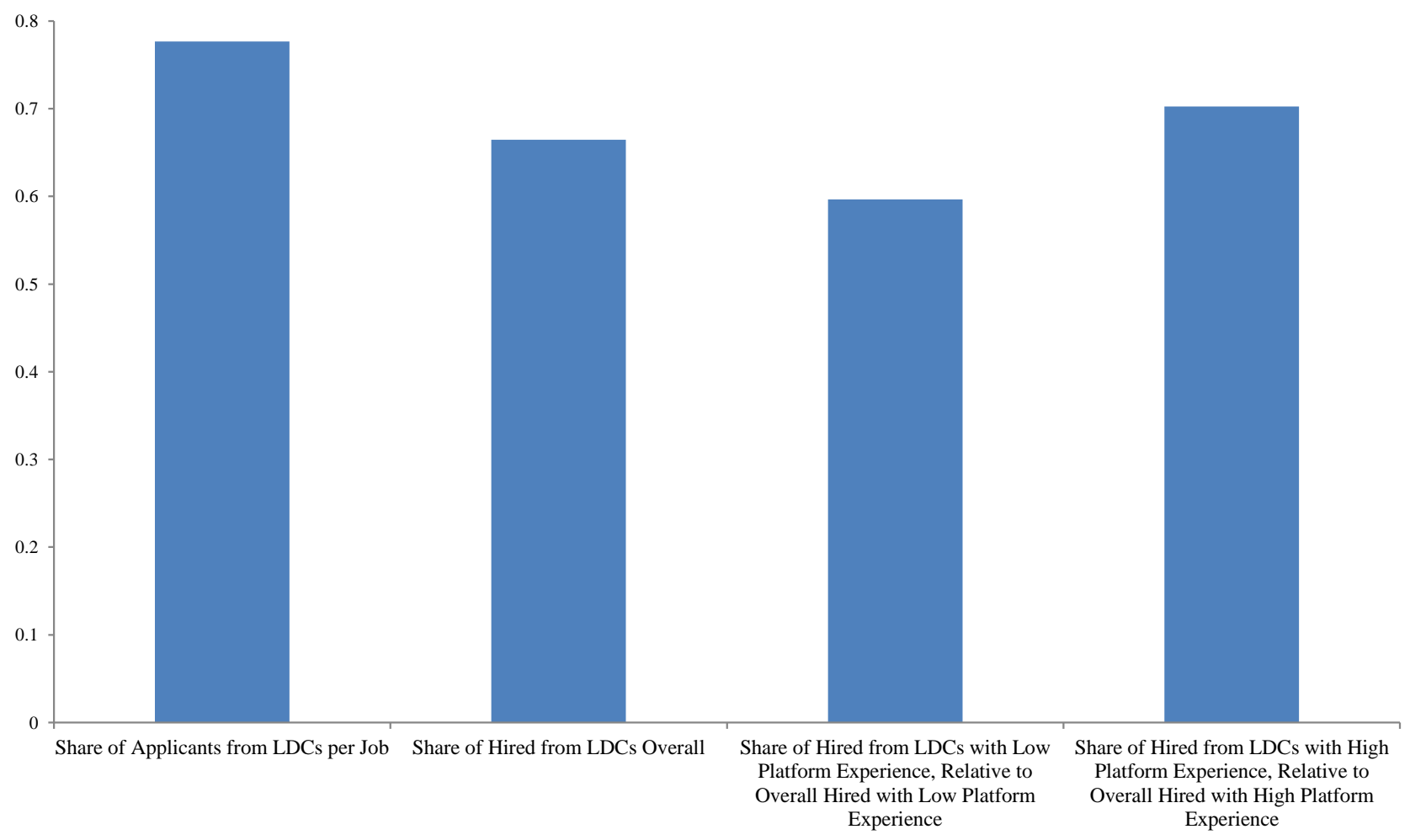

The first column in the graph reports the average share of LDC applications per job. The second column displays the share of LDC applicants that were hired overall; the third column reports the share of LDC applicants with low experience that were hired out of all those with low experience that were hired, and the fourth column reports the share of LDC applicants with high experience that were hired out of all those with high experience that were hired. 
Figure 3: Estimated Likelihood of Being Hired by Platform Experience (in quintiles) and LDC Status

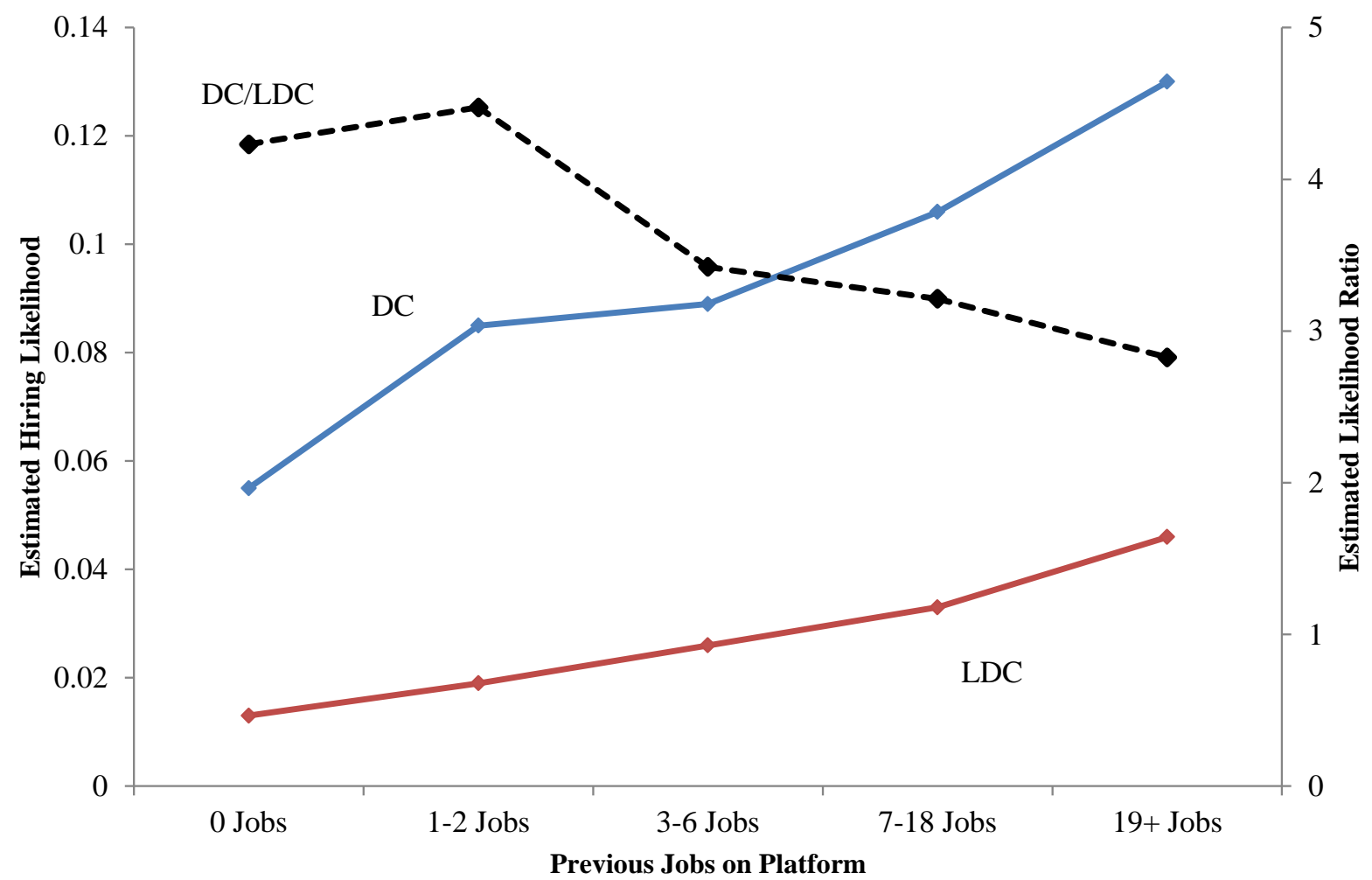

This figure reports the estimated likelihood of being hired for DC and LDC applicants, as a function of their experience expressed in sample quantiles. The values for 0 previous jobs are taken from the summary statistics, and the values for the other categories are estimated using the odd ratios in Table A8. 


\section{Table 1: Variable Definitions}

\begin{tabular}{|c|c|}
\hline Variable Name & Variable Definition \\
\hline \multicolumn{2}{|l|}{ Dependent Variables: } \\
\hline Applicant Success & Equals 1 if Applicant is Hired for the Job, 0 Otherwise \\
\hline Log(Wage Bid) & Log of the Bid Applicant makes on an Hourly Wage Job \\
\hline Log(Fixed Price Bid) & Log of the Bid Applicant makes on a Fixed Price Job \\
\hline Interviewed & Equals 1 if Applicant is Interviewed for the Job, 0 Otherwise \\
\hline Short Listed & Equals 1 if Applicant is ShortListed for the Job, 0 Otherwise \\
\hline \multicolumn{2}{|l|}{ Key Explanatory Variables: } \\
\hline \multicolumn{2}{|l|}{ Primary: } \\
\hline LDC & Equals 1 if Applicant is from a LDC, 0 Otherwise \\
\hline Platform Experience & $\begin{array}{l}\text { Equals } 1 \text { if Applicant has More Than the Sample Median Number of Prior Jobs } \\
\text { on the Platform, } 0 \text { Otherwise }\end{array}$ \\
\hline \multicolumn{2}{|l|}{ Secondary: } \\
\hline Job Type & $\begin{array}{l}5 \text { Types of Jobs with at Least } 500 \text { Occurances in Sample: Administrative } \\
\text { Services, Sales \& Marketing, Software Development, Web Development, } \\
\text { Writing \& Translation }\end{array}$ \\
\hline Fixed Price & Equals 1 if Contract is Fixed Price, 0 if Contract is Hourly \\
\hline Employer Experience & Number of Prior Hires Employer has Made on Platform \\
\hline \multicolumn{2}{|l|}{ Contractor Controls: } \\
\hline Off Platform Work Experience $(0 / 1)$ & $\begin{array}{l}\text { Equals } 1 \text { if Applicant has More than the Sample Median Number of Jobs } \\
\text { Outside of the Platform, } 0 \text { Otherwise }\end{array}$ \\
\hline Fraction of Cover Letter that is Original & $\begin{array}{l}\text { Fraction of Applicant Cover Letter that Has Not Appeared in Cover Letters } \\
\text { Submitted to Other Platform Jobs Applicant has Applied for }\end{array}$ \\
\hline Profile Picture & Equals 1 if Applicant has Profile Picture, 0 Otherwise \\
\hline oDesk Rating Score & Applicant's Rating on the Platform \\
\hline No oDesk rating Score & Equals 1 if Applicant has no Rating on Platform, 0 Otherwise \\
\hline Average oDesk Test Score & $\begin{array}{l}\text { Equals } 1 \text { if Applicant's Average Platform Test Score is Above the Sample } \\
\text { Median, } 0 \text { Otherwise }\end{array}$ \\
\hline Number of oDesk Test Scores & $\begin{array}{l}\text { Equals } 1 \text { if Applicant has Completed More than the Sample Median Number of } \\
\text { Platform Tests, } 0 \text { Otherwise }\end{array}$ \\
\hline Agency Member & $\begin{array}{l}\text { Equals } 1 \text { if Applicant is a Member of an Employment Agency on Platform, } 0 \\
\text { Otherwise }\end{array}$ \\
\hline Education & $\begin{array}{l}\text { Equals } 1 \text { if Applicant has some college education, } 2 \text { if Applicant has a } \\
\text { Bachelor's Degree, } 3 \text { if Applicant has a Master's Degree, } 4 \text { if Applicant has a } \\
\text { Doctorate and } 0 \text { Otherwise }\end{array}$ \\
\hline $\log (\mathrm{Bid})$ & Log of Applicant Bid on any Contract \\
\hline Current Offline Employment Status & Equals 1 if Applicant is Currently Employed Outside of Platform, 0 Otherwise \\
\hline Employer Initiated Application & Equals 1 if Employer Invited Applicant to Apply, 0 Otherwise \\
\hline Prior Hire & $\begin{array}{l}\text { Equals } 1 \text { if Applicant has been Previously Hired by Employer of Job Applied to, } \\
0 \text { Otherwise }\end{array}$ \\
\hline \multicolumn{2}{|l|}{ Job Characteristics: } \\
\hline Other Job Types & $\begin{array}{l}4 \text { Job Types with less than } 500 \text { Occurences in Sample: Business Services, } \\
\text { Customer Services, Design \& Multimedia and Networks \& Information } \\
\text { Systems }\end{array}$ \\
\hline Number of Interviews & Number of Interviews Performed before Hire \\
\hline Job Budget & $\begin{array}{l}\text { Amount Employer is Willing to Pay a Contractor to Complete the Job, Fixed } \\
\text { Price Jobs Only }\end{array}$ \\
\hline Final Amount Paid & Total Amount Paid to Hired Contractor, Closed Contracts Only \\
\hline Number of Applicants & Number of Contractor Applications for Job \\
\hline
\end{tabular}


Table 2: Contractor Descriptive Statistics

\begin{tabular}{|c|c|c|c|}
\hline Sample & $\begin{array}{c}\text { (1) } \\
\text { Full Sample } \\
\text { Mean (SD) } \\
\text { Median } \\
\end{array}$ & $\begin{array}{c}(2) \\
\text { DC Contractors } \\
\text { Mean (SD) } \\
\text { Median } \\
\end{array}$ & $\begin{array}{c}(3) \\
\text { LDC Contractors } \\
\text { Mean (SD) } \\
\text { Median } \\
\end{array}$ \\
\hline Applicant Success (0/1) & 0.035 & 0.087 & 0.027 \\
\hline Contractor-LDC (0/1) & 0.867 & & \\
\hline Number of Prior oDesk Contracts & $\begin{array}{c}13.066 \\
(25.612)\end{array}$ & $\begin{array}{c}12.868 \\
(18.261)\end{array}$ & $\begin{array}{c}13.096 \\
(25.181)\end{array}$ \\
\hline High Platform Experience (0/1) & 0.482 & 0.439 & 0.488 \\
\hline Off Platform Work Experience (0/1) & 0.321 & 0.390 & 0.310 \\
\hline Education & $\begin{array}{c}1.196 \\
(1.182) \\
1\end{array}$ & $\begin{array}{c}0.916 \\
(1.174) \\
0\end{array}$ & $\begin{array}{c}1.237 \\
(1.178) \\
2\end{array}$ \\
\hline Current non-oDesk Employment Status (0/1) & 0.517 & 0.559 & 0.510 \\
\hline Average oDesk Test Score $(0 / 1)$ & 0.499 & 0.682 & 0.473 \\
\hline Number of oDesk Tests $(0 / 1)$ & 0.409 & 0.393 & 0.412 \\
\hline Wage Bid & $\begin{array}{c}8.242 \\
(13.418) \\
5.56\end{array}$ & $\begin{array}{c}16.871 \\
(17.764) \\
13.33\end{array}$ & $\begin{array}{c}7.147 \\
(12.338) \\
4.44\end{array}$ \\
\hline Fixed Price Bid & $\begin{array}{c}10.177 \\
(16.286) \\
7.78\end{array}$ & $\begin{array}{c}17.736 \\
(15.872) \\
13.89\end{array}$ & $\begin{array}{c}8.690 \\
(15.950) \\
6.67\end{array}$ \\
\hline Profile Wage & $\begin{array}{c}6.490 \\
(19.797) \\
4\end{array}$ & $\begin{array}{c}14.756 \\
(15.040) \\
12\end{array}$ & $\begin{array}{c}5.226 \\
(20.130) \\
3\end{array}$ \\
\hline Profile Picture $(0 / 1)$ & 0.838 & 0.811 & 0.842 \\
\hline Agency Membership (0/1) & 0.232 & 0.097 & 0.253 \\
\hline Employer Initiated Application (0/1) & 0.075 & 0.172 & 0.060 \\
\hline oDesk Rating Score & $\begin{array}{c}3.177 \\
(2.229) \\
4.7\end{array}$ & $\begin{array}{c}3.124 \\
(2.309) \\
5\end{array}$ & $\begin{array}{c}3.185 \\
(2.217) \\
4.7\end{array}$ \\
\hline No rating Score $(0 / 1)$ & 0.695 & 0.662 & 0.700 \\
\hline Previously Hired by Employer (0/1) & 0.005 & 0.013 & 0.003 \\
\hline Interviewed (0/1) & 0.111 & 0.188 & 0.099 \\
\hline Short Listed $(0 / 1)$ & 0.038 & 0.050 & 0.036 \\
\hline Fraction of Cover Letter that is Original & $\begin{array}{c}0.301 \\
(0.346)\end{array}$ & $\begin{array}{c}0.479 \\
(0.371)\end{array}$ & $\begin{array}{c}0.276 \\
(0.334)\end{array}$ \\
\hline Number of Observations & $\begin{array}{c}0.143 \\
420,833\end{array}$ & $\begin{array}{c}0.5 \\
55,912\end{array}$ & $\begin{array}{c}0.111 \\
364,921\end{array}$ \\
\hline
\end{tabular}

This table reports summary statistics at the applicant-job level. For variables that are not binary, the standard deviation and the median are reported in addition to the mean. 
Table 3: Job and Employer Summary Statistics

\begin{tabular}{|c|c|}
\hline & $\begin{array}{c}\text { Mean (SD) } \\
\text { Median }\end{array}$ \\
\hline Number of Prior Hires on oDesk & $\begin{array}{c}16.346 \\
(46.002) \\
4\end{array}$ \\
\hline Job Type: $(0 / 1)$ & \\
\hline Administrative Services & 0.100 \\
\hline Business Services & 0.030 \\
\hline Customer Services & 0.008 \\
\hline Design \& Multimedia & 0 \\
\hline Networks \& Information Systems & 0 \\
\hline Sales \& Marketing & 0.089 \\
\hline Software Development & 0.069 \\
\hline Web Development & 0.280 \\
\hline Writing \& Translation & 0.193 \\
\hline Number of Interviews & $\begin{array}{c}3.214 \\
(4.857) \\
2\end{array}$ \\
\hline Fixed Price Contract $(0 / 1)$ & 0.508 \\
\hline Job Budget & $\begin{array}{c}172.882 \\
(947.152) \\
50\end{array}$ \\
\hline Final Amount Paid & $\begin{array}{c}458.931 \\
(1917.097) \\
53.675\end{array}$ \\
\hline Number of Applicants & $\begin{array}{c}29.005 \\
(44.385) \\
18\end{array}$ \\
\hline Number of Observations & 14,617 \\
\hline
\end{tabular}

This table reports characteristics at the employer-job level. For variables that are not binary, the standard deviation and the median are reported in addition to the mean. Employers indicate how big the budget is for a job only if the job offers a fixed price contract. Only jobs that were completed during our period of observation have a final amount paid observation. 
Table 4: LDC Status and oDesk Experience

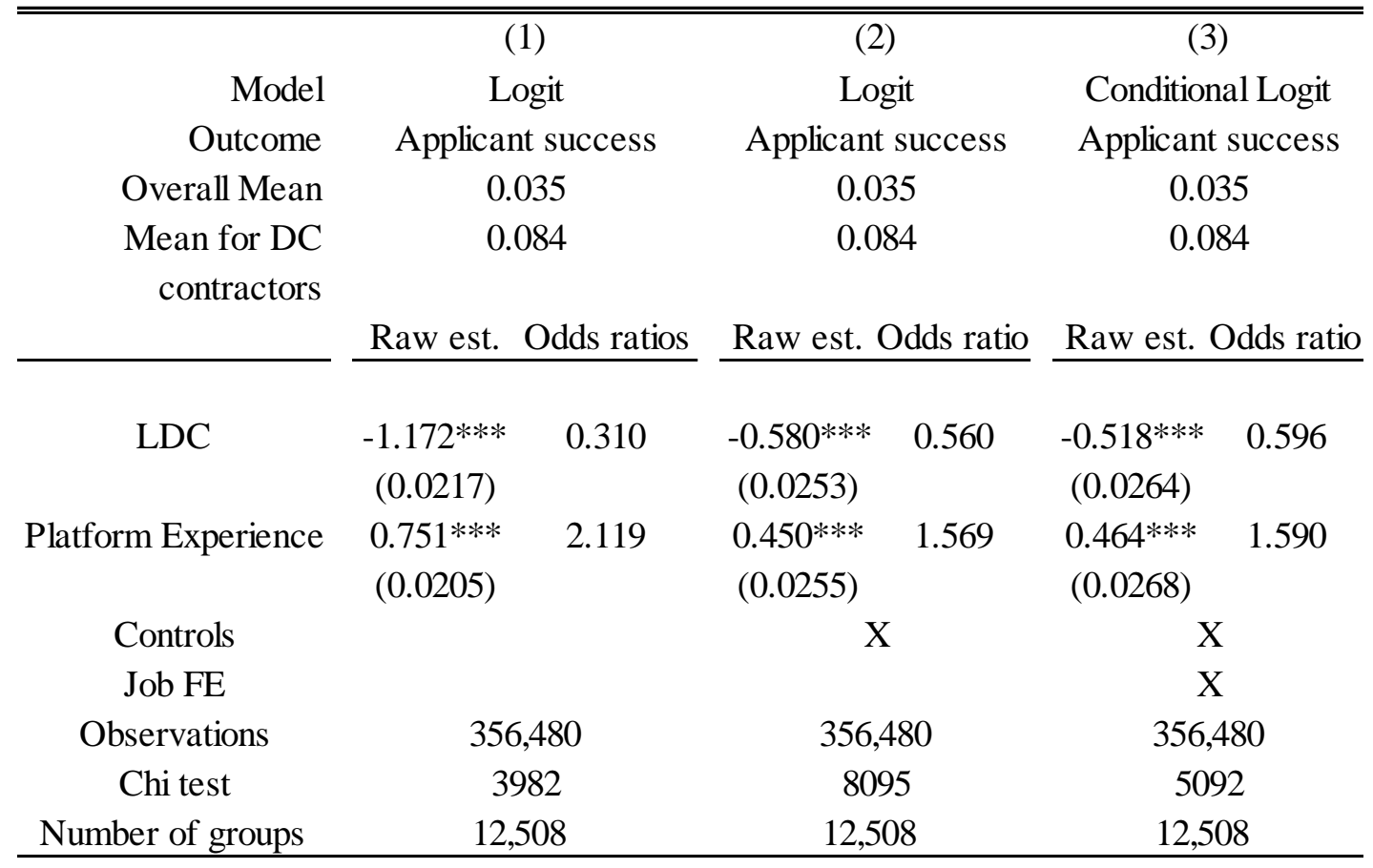

The sample is restricted to jobs posted by employers from DCs and jobs for which one contractor was hired. Standard errors clustered at the job level are reported in parentheses. $* p<0.10 * * p<0.05 * * * p<0.01$. 
Table 5: Differential Impact of Platform Specific Experience for LDC Contractors

\begin{tabular}{|c|c|c|}
\hline Outcome & \multirow{2}{*}{\multicolumn{2}{|c|}{$\begin{array}{c}\text { Applicant success } \\
0.035\end{array}$}} \\
\hline Overall Mean & & \\
\hline Mean for DC contractors & \multicolumn{2}{|c|}{0.067} \\
\hline & \multicolumn{2}{|c|}{ Raw est. Odds ratio } \\
\hline LDC & $\begin{array}{l}-0.718 * * * \\
(0.0373)\end{array}$ & 0.488 \\
\hline Platform Experience & $\begin{array}{l}0.209 * * * \\
(0.0442)\end{array}$ & 1.233 \\
\hline LDC X Platform & $0.346^{* * *}$ & 1.413 \\
\hline Experience & $(0.0475)$ & \\
\hline Controls & $x$ & \\
\hline Job FE & $x$ & \\
\hline Observations & 356 & \\
\hline Chi test & 50 & \\
\hline Number of groups/cases & 12,5 & \\
\hline
\end{tabular}

Results are from a conditional logit regression. The sample is restricted to jobs posted by employers from DCs and jobs for which one contractor was hired. Standard errors clustered at the job level are reported in parentheses.

$* p<0.10 * * p<0.05 * * * p<0.01$. 
Table 6: Differential Impact of Platform Specific Experience by Job Type

\begin{tabular}{|c|c|c|c|c|c|c|c|c|c|c|}
\hline & \multicolumn{2}{|c|}{ (1) } & \multicolumn{2}{|c|}{ (2) } & \multicolumn{2}{|c|}{ (3) } & \multicolumn{2}{|c|}{ (4) } & \multicolumn{2}{|c|}{ (5) } \\
\hline Sample & \multicolumn{2}{|c|}{ Administrative Jobs } & \multicolumn{2}{|c|}{ Web Development Jobs } & \multicolumn{2}{|c|}{ Writing Jobs } & \multicolumn{2}{|c|}{$\begin{array}{c}\text { Software Development } \\
\text { Jobs }\end{array}$} & \multicolumn{2}{|c|}{ Marketing Jobs } \\
\hline Outcome & \multicolumn{2}{|c|}{ Applicant success } & \multicolumn{2}{|c|}{ Applicant success } & \multicolumn{2}{|c|}{ Applicant success } & \multicolumn{2}{|c|}{ Applicant success } & \multicolumn{2}{|c|}{ Applicant success } \\
\hline Overall Mean & \multicolumn{2}{|c|}{0.014} & \multicolumn{2}{|c|}{0.042} & \multicolumn{2}{|c|}{0.063} & \multicolumn{2}{|c|}{0.056} & \multicolumn{2}{|c|}{0.025} \\
\hline Mean for DC contractors & \multicolumn{2}{|c|}{0.031} & \multicolumn{2}{|c|}{0.081} & \multicolumn{2}{|c|}{0.093} & \multicolumn{2}{|c|}{0.078} & \multicolumn{2}{|c|}{0.083} \\
\hline & Raw est. & dds ratios & Raw est. & Odds ratio & Raw est. & dds ratio & Raw est. & Odds ratio & Raw est. ( & dds ratio \\
\hline LDC & $\begin{array}{c}-1.087 * * * \\
(0.116)\end{array}$ & 0.337 & $\begin{array}{c}-0.551 * * * \\
(0.0777)\end{array}$ & 0.576 & $\begin{array}{l}-0.895 * * * \\
(0.0829)\end{array}$ & 0.409 & $\begin{array}{c}-0.359 * * * \\
(0.137)\end{array}$ & 0.698 & $\begin{array}{c}-0.812 * * * \\
(0.139)\end{array}$ & 0.444 \\
\hline Platform Experience & $\begin{array}{l}0.341 * * \\
(0.155)\end{array}$ & 1.406 & $\begin{array}{l}0.202 * * \\
(0.0963)\end{array}$ & 1.223 & $\begin{array}{c}0.127 \\
(0.0836)\end{array}$ & 1.136 & $\begin{array}{l}0.363 * * \\
(0.175)\end{array}$ & 1.438 & $\begin{array}{c}0.227 \\
(0.172)\end{array}$ & 1.255 \\
\hline LDC X Platform Experience & $\begin{array}{l}0.339 * * \\
(0.159)\end{array}$ & 1.403 & $\begin{array}{c}0.297 * * * \\
(0.102)\end{array}$ & 1.345 & $\begin{array}{c}0.478^{* * * *} \\
(0.101)\end{array}$ & 1.613 & $\begin{array}{l}-0.0566 \\
(0.186)\end{array}$ & 0.945 & $\begin{array}{l}0.426 * * \\
(0.180)\end{array}$ & 1.532 \\
\hline Controls & & & & $X$ & $X$ & & & $X$ & X & \\
\hline Job FE & & & & $X$ & $X$ & & & $X$ & $X$ & \\
\hline Observations & 90 & & & 754 & 35,2 & & & 409 & 44,7 & \\
\hline Chi test & 68 & & & 75 & 10 & & & 0.4 & 418 & \\
\hline Number of groups/cases & 1,3 & & & 61 & 2,20 & & & 58 & 1,10 & \\
\hline
\end{tabular}

The sample is split by job type, limited to jobs with at least 500 postings in the final sample. The sample is restricted to jobs posted by employers from DCs and jobs for which one contractor was hired. Standard errors clustered at the job level are reported in parentheses. $* p<0.10 * * p<0.05 * * * p<0.01$. 
Table 7: Differential Impact of Platform Specific Experience for LDC Contractors on Wages

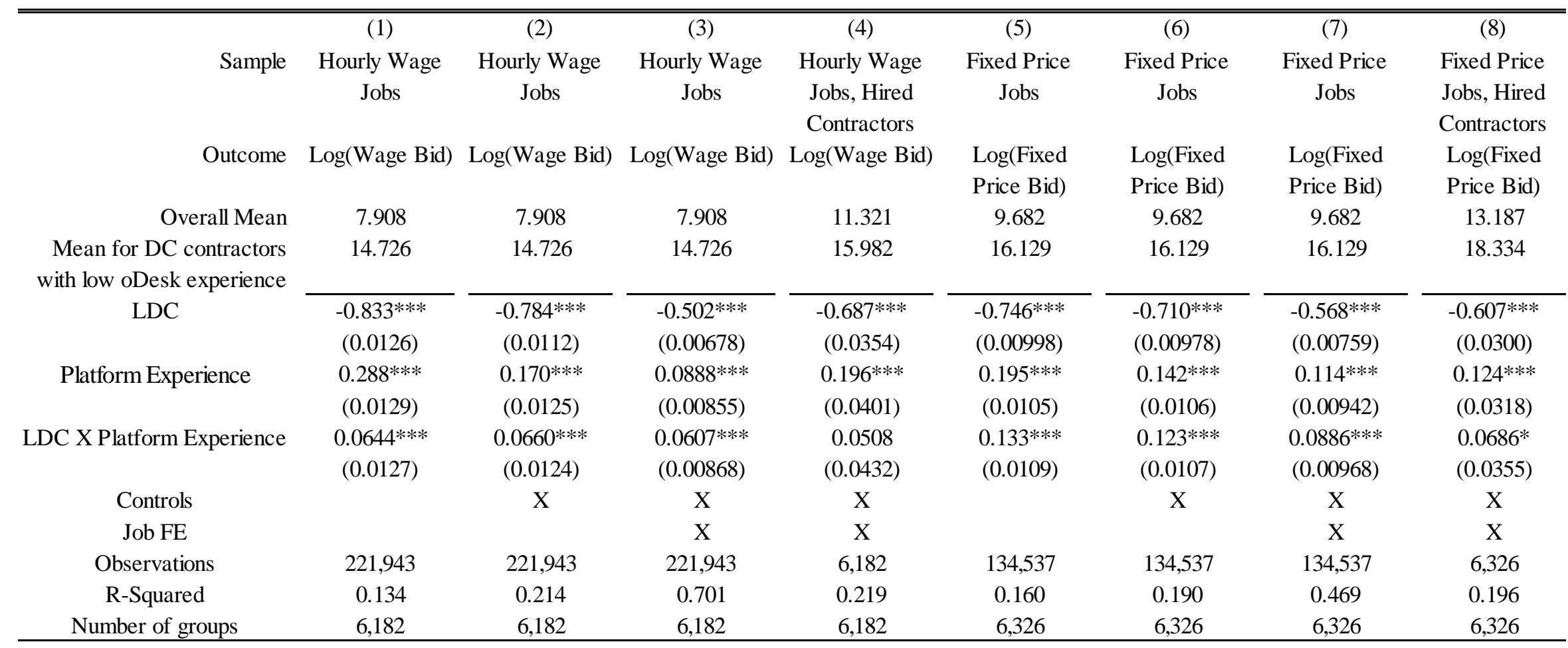

This table reports estimates from linear regressions. Standard errors are clustered by jobs are reported in parentheses. $* p<0.10 * * p<0.05 * * * p<0.01$. 
Table 8: Differential Impact of Platform Specific Experience by Employer Experience

\begin{tabular}{|c|c|c|c|c|c|c|c|c|}
\hline & ( & & ( & & & 3) & & 4) \\
\hline Sample & No Pri & Hires & Prior $\mathrm{I}$ & res $>0$ & $\begin{array}{l}\text { Below N } \\
\text { Hires (Pri }\end{array}$ & $\begin{array}{l}\text { edian Prior } \\
\text { r Hires }<=5 \text { ) }\end{array}$ & $\begin{array}{l}\text { Above } \mathrm{M} \\
\text { Hires }(\mathrm{Pr}\end{array}$ & $\begin{array}{l}\text { dian Prior } \\
\text { or Hires }>5 \text { ) }\end{array}$ \\
\hline Outcome & Applican & success & Applican & success & Applica & th success & Applicar & $t$ success \\
\hline Overall Mean & 0. & & 0. & & & 038 & & 32 \\
\hline Mean for DC contractors & & & 0. & & & 069 & & 64 \\
\hline & Raw est. & dds ratios & Raw est. & dds ratios & Raw est. & Odds ratio & Raw est. & Odds ratio \\
\hline LDC & $\begin{array}{c}-0.656 * * * \\
(0.0680)\end{array}$ & 0.519 & $\begin{array}{c}-0.744 * * * \\
(0.0446)\end{array}$ & 0.475 & $\begin{array}{c}-0.692 * * * \\
(0.0499)\end{array}$ & 0.500 & $\begin{array}{c}-0.753 * * * \\
(0.0562)\end{array}$ & 0.471 \\
\hline Platform Experience & $0.312 * * *$ & 1.366 & $0.165 * * *$ & 1.179 & $0.230 * * *$ & 1.259 & $0.184 * * *$ & 1.202 \\
\hline LDC X Platform Experience & $\begin{array}{c}(0.0796) \\
0.204 * * \\
(0.0857)\end{array}$ & 1.227 & $\begin{array}{c}(0.0532) \\
0.406 * * * \\
(0.0571)\end{array}$ & 1.501 & $\begin{array}{c}(0.0582) \\
0.297 * * * \\
(0.0629)\end{array}$ & 1.346 & $\begin{array}{c}(0.0680) \\
0.409 * * * \\
(0.0724)\end{array}$ & 1.505 \\
\hline Controls & & & r & & & $\mathrm{X}$ & & $x$ \\
\hline Job FE & & & & & & $\mathrm{X}$ & & $x$ \\
\hline Observations & 87 & & 269 & & & 5,432 & &, 048 \\
\hline Chi test & & & & & & 616 & & 21 \\
\hline Number of groups & 3,7 & & & & & 60 & & \\
\hline
\end{tabular}

The sample is split by employer experience level: we first distinguish employer with no previous experience from those with experience, and then between employers below and above the median level of previous experience as given by prior hires. The median number of prior hires in our sample is 5 . Results are from conditional logit regressions. The sample is restricted to jobs posted by employers from DCs and jobs for which one contractor was hired. Standard errors clustered at the job level are reported in parentheses. $* p<0.10 * * p<0.05 * * * p<0.01$. 
Table 9: Differential Impact of Platform-Specific Experience by Contract Type

\begin{tabular}{|c|c|c|c|c|}
\hline \multirow{6}{*}{$\begin{array}{r}\text { Sample } \\
\text { Outcome } \\
\text { Overall Mean } \\
\text { Mean for DC contractors } \\
\text { with low oDesk experience }\end{array}$} & \multicolumn{2}{|c|}{ (1) } & \multicolumn{2}{|c|}{ (2) } \\
\hline & \multicolumn{2}{|c|}{ Hourly Contracts } & \multicolumn{2}{|c|}{ Fixed Price Contracts } \\
\hline & \multicolumn{2}{|c|}{ Applicant success } & \multicolumn{2}{|c|}{ Applicant success } \\
\hline & \multicolumn{2}{|c|}{0.028} & \multicolumn{2}{|c|}{0.047} \\
\hline & \multicolumn{2}{|c|}{0.051} & \multicolumn{2}{|c|}{0.084} \\
\hline & Raw est. & dds ratios & Raw est. & dds ratio \\
\hline LDC & $\begin{array}{c}-0.730 * * * \\
(0.0570)\end{array}$ & 0.482 & $\begin{array}{c}-0.713 * * * \\
(0.0502)\end{array}$ & 0.490 \\
\hline Platform Experience & $0.229 * * *$ & 1.258 & $0.197 * * *$ & 1.218 \\
\hline & $(0.0686)$ & & $(0.0585)$ & \\
\hline LDC X Platform Experience & $0.293 * * *$ & 1.340 & $0.412 * * *$ & 1.510 \\
\hline & $(0.0717)$ & & $(0.0646)$ & \\
\hline Controls & & & & \\
\hline Job FE & & & & \\
\hline Observations & 221 & & 134 & \\
\hline Chi test & & & 25 & \\
\hline Number of groups & 6,1 & & 6,3 & \\
\hline
\end{tabular}

The sample is split by contract type: hourly vs. fixed price. Results are from conditional logit regressions. The sample is restricted to jobs posted by employers from DCs and jobs for which one contractor was hired. Standard errors clustered at the job level are reported in parentheses. $* p<0.10 * * p<0.05 * * * p<0.01$. 


\section{APPENDIX}

\section{A simple theoretical framework}

Suppose that an applicant contract worker can be of two quality levels $\theta: \bar{\theta}$ and 0 , where $\bar{\theta}>0$. Assume the quality is positive with probability $\beta \geq 1 / 2$ and 0 with the complementary probability $1-\beta$. Therefore, the ex-ante expected quality of a worker is $\beta \bar{\theta}$. More precisely, the prior on $\beta$ held by prospective employers varies according to the origin of the applicants. It is higher for DC applicants than for LDC applicants. Note also the variance of the ability level is a function of $\beta$. In particular, the highest variance is when $\beta=1 / 2$. Given our restriction on the values of $\beta$, the quality of LDC applicants is expected to be lower and also more uncertain. Assuming $\beta \geq 1 / 2$ (rather than not constraining the value within any interval) can be justified on a number of grounds. First, note in this binomial case the highest variance is reached when $\beta \geq 1 / 2$. Therefore, if we believe that an issue with hiring LDCs is uncertainty, it makes sense to have the LDCs closer to the level of $\beta$ that is higher. Second, as also described below, one could think of $\beta$ already incorporating information about an applicant's quality, and one can argue this leads to a first screening where employers keep only contractors for whom they expect positive quality with a higher probability than the "toss of a coin." Suppose now there is a signal, $y$, which the employer may observe. She is more likely to observe the signal if the applicant is of high quality. Formally:

$$
\begin{aligned}
& \operatorname{Prob}(y=1 \mid \theta=\bar{\theta})=\alpha^{\prime} ; \\
& \operatorname{Prob}(y=1 \mid \theta=0)=\alpha,
\end{aligned}
$$

where $0<\alpha<\alpha^{\prime} \leq 1$. The difference between $\alpha$ and $\alpha^{\prime}$ can be considered to be the degree of "informativeness" of the signal. If the two probabilities are the same, then the signal does not tell the employer anything more about the quality of an applicant. Upon observing the signal, the employer updates her beliefs about the quality of each applicant. In particular:

$$
\operatorname{Prob}(\theta=\bar{\theta} \mid y=1)=\frac{\alpha^{\prime} \beta}{\alpha^{\prime} \beta+\alpha(1-\beta)} .
$$

Note that, if $\alpha^{\prime}=\alpha$, then $\operatorname{Prob}(\theta=\bar{\theta} \mid y=1)=\beta$, so there is no updating. Therefore, the change $\Delta$ in the expected quality of an applicant is given by:

$$
\Delta=\frac{\alpha^{\prime} \beta}{\alpha^{\prime} \beta+\alpha(1-\beta)} \bar{\theta}-\beta \bar{\theta}=\frac{\left(\alpha^{\prime}-\alpha\right)(1-\beta)}{\alpha+\beta\left(\alpha^{\prime}-\alpha\right)} \beta \bar{\theta}
$$

Now, the sign of $\partial \Delta / \partial \beta$ is opposite to the sign of the following expression:

$$
\left(\alpha^{\prime}-\alpha\right) \beta^{2}+2 \alpha \beta-\alpha
$$

This expression is always positive for $\beta \geq 1 / 2$; therefore $\Delta$ is decreasing in $\beta$ if $\beta \geq 1 / 2$. The increment in expected quality upon observing the signal $y$ is greater for applicants with ex-ante lower expected (and more uncertain) quality. ${ }^{1}$ Note that the relative increase in expected quality can be expressed by $\Delta / \beta \bar{\theta}=\frac{\left(\alpha^{\prime}-\alpha\right)(1-\beta)}{\alpha+\beta\left(\alpha^{\prime}-\alpha\right)}$, which is, again, decreasing in $\beta$ for all $\beta$.

\footnotetext{
${ }^{1}$ The differential impact of the signal can also be obtained from a framework where we assume an equal prior expected quality, but different variability according to the origin of workers. For example, consider a case of three levels of quality: $\bar{\theta}, \underline{\theta}$ and 0 , where $\bar{\theta}>\underline{\theta}>0$. For simplicity (and with some loss of generality), assume that the highest quality level is twice the mid-level quality: $\bar{\theta}=2 \underline{\theta}$. The probability distribution over quality is such that: $\theta$ $=\left\{\begin{array}{c}0 \text { with prob }(1-\beta) / 2 \\ \underline{\theta} \text { with prob } \beta \\ \bar{\theta} \text { with prob }(1-\beta) / 2\end{array}\right.$ Assume $\beta \geq \frac{1}{3}$ (so the distribution is "single peaked"). Note that $\mathrm{E}(\theta)=\underline{\theta}$ regardless of the value of $\beta$, and that the variance if this probability distribution is decreasing in $\beta$ for $\beta \geq 1 / 3$. Suppose that the quality signals is such that:

$\operatorname{Prob}(y=1 \mid \theta=\bar{\theta})=\bar{\alpha}$

$\operatorname{Prob}(y=1 \mid \theta=\underline{\theta})=\underline{\alpha}$

$\operatorname{Prob}(y=1 \mid \theta=0)=\alpha_{0}=0$,

where $\bar{\alpha}>\underline{\alpha}$. In this case, it can be shown that the change in the expected quality of an applicant is given by
} 
Table A1: Descriptive Statistics Comparing Jobs Included and Dropped from Sample

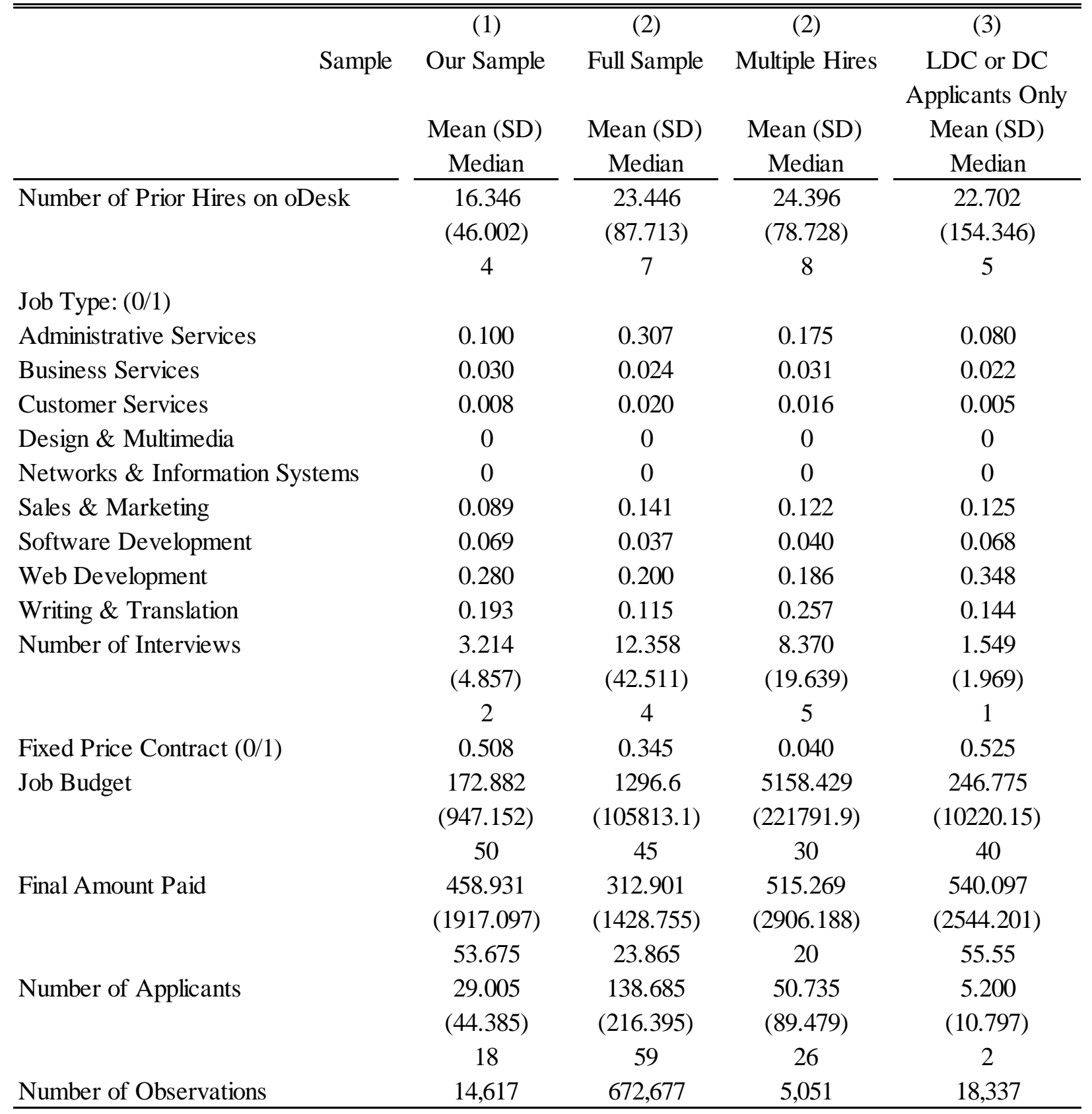

Employers indicate how big the budget is for a job only if the job offers a fixed price contract. Only jobs that were completed during our period of observation have a final amount paid observation.

$$
\Delta=\frac{2 \bar{\alpha}-2(\bar{\alpha}-\underline{\alpha}) \beta}{\bar{\alpha}-(\bar{\alpha}-2 \underline{\alpha}) \beta} \underline{\theta}-\underline{\theta},
$$

And this is decreasing in $\beta$. Equivalently, the change in expected value is higher when $\beta$ is smaller, i.e. when the variance is higher. 
Table A2: Contractor Descriptive Statistics for Sample Including Jobs with Multiple Hires

\begin{tabular}{|c|c|c|c|}
\hline \multirow{5}{*}{ Sample } & (1) & \multirow{2}{*}{$\begin{array}{l}\text { (2) } \\
\text { DC }\end{array}$} & \multirow{2}{*}{$\begin{array}{c}(3) \\
\text { LDC }\end{array}$} \\
\hline & Full Sample & & \\
\hline & & Contractors & Contractors \\
\hline & Mean (SD) & Mean (SD) & Mean (SD) \\
\hline & Median & Median & Median \\
\hline Applicant Success (0/1) & 0.049 & 0.097 & 0.041 \\
\hline Contractor-LDC (0/1) & 0.856 & & \\
\hline \multirow[t]{3}{*}{ Number of Prior oDesk Contracts } & 12.163 & 10.915 & 12.372 \\
\hline & $(24.467)$ & $(26.085)$ & $(24.179)$ \\
\hline & 4 & 2 & 4 \\
\hline High Platform Experience (0/1) & 0.460 & 0.439 & 0.488 \\
\hline Off Platform Work Experience (0/1) & 0.320 & 0.390 & 0.310 \\
\hline \multirow[t]{3}{*}{ Education } & 1.168 & 0.837 & 1.222 \\
\hline & $(1.173)$ & $(1.145)$ & $(1.169)$ \\
\hline & 1 & 0 & 2 \\
\hline Current non-oDesk Employment Status (0/1) & 0.502 & 0.516 & 0.500 \\
\hline Average oDesk Test Score (0/1) & 0.500 & 0.680 & 0.472 \\
\hline Number of oDesk Tests $(0 / 1)$ & 0.406 & 0.370 & 0.412 \\
\hline \multirow[t]{3}{*}{ Wage Bid } & 7.457 & 15.206 & 6.468 \\
\hline & $(14.543)$ & $(17.537)$ & $(13.837)$ \\
\hline & 4.44 & 11.11 & 3.7 \\
\hline \multirow[t]{3}{*}{ Fixed Price Bid } & 9.769 & 15.786 & 8.269 \\
\hline & $(16.866)$ & $(17.537)$ & $(16.353)$ \\
\hline & 7 & 11.11 & 5.56 \\
\hline \multirow[t]{3}{*}{ Profile Wage } & 6.125 & 13.389 & 4.910 \\
\hline & $(17.555)$ & $(16.780)$ & $(17.288)$ \\
\hline & 3.33 & 10 & 3 \\
\hline Profile Picture $(0 / 1)$ & 0.843 & 0.780 & 0.853 \\
\hline Agency Membership (0/1) & 0.219 & 0.088 & 0.241 \\
\hline Employer Initiated Application (0/1) & 0.106 & 0.294 & 0.075 \\
\hline \multirow[t]{3}{*}{ oDesk Rating Score } & 3.074 & 2.804 & 3.119 \\
\hline & $(2.259)$ & $(2.376)$ & (2.236) \\
\hline & 4.6 & 4.5 & 4.6 \\
\hline No rating Score $(0 / 1)$ & 0.673 & 0.597 & 0.686 \\
\hline Previously Hired by Employer (0/1) & 0.005 & 0.012 & 0.004 \\
\hline Interviewed (0/1) & 0.130 & 0.199 & 0.118 \\
\hline Short Listed (0/1) & 0.036 & 0.042 & 0.035 \\
\hline \multirow[t]{3}{*}{ Fraction of Cover Letter that is Original } & 0.305 & 0.496 & 0.279 \\
\hline & $(0.349)$ & $(0.375)$ & $(0.337)$ \\
\hline & 0.143 & 0.5 & 0.111 \\
\hline Number of Observations & 672,677 & 96,559 & 576,118 \\
\hline
\end{tabular}


Table A3: Contractor Descriptive Statistics across Employer Experience Levels

\begin{tabular}{|c|c|c|c|c|}
\hline \multirow{5}{*}{ Sample } & $(1)$ & (2) & (3) & (4) \\
\hline & No Prior & Prior & Below Median & Above Median \\
\hline & Hires & Hires $>0$ & Prior Hires & Prior Hires \\
\hline & Mean (SD) & Mean (SD) & Mean (SD) & Mean (SD) \\
\hline & Median & Median & Median & Median \\
\hline Applicant Success (0/1) & 0.043 & 0.033 & 0.038 & 0.032 \\
\hline Contractor-LDC (0/1) & 0.871 & 0.892 & 0.882 & 0.891 \\
\hline \multirow[t]{3}{*}{ Number of Prior oDesk Contracts } & 13.740 & 12.877 & 13.422 & 12.726 \\
\hline & $(26.540)$ & $(25.391)$ & $(25.147)$ & (25.159) \\
\hline & 4 & 4 & 4 & 4 \\
\hline High Platform Experience (0/1) & 0.494 & 0.483 & 0.490 & 0.481 \\
\hline Off Platform Work Experience (0/1) & 0.317 & 0.317 & 0.315 & 0.319 \\
\hline \multirow[t]{3}{*}{ Education } & 1.213 & 1.218 & 1.216 & 1.218 \\
\hline & (1.192) & $(1.180)$ & (1.188) & (1.177) \\
\hline & 1 & 1 & 1 & 1 \\
\hline $\begin{array}{l}\text { Current non-oDesk Employment Status } \\
(0 / 1)\end{array}$ & 0.522 & 0.520 & 0.521 & 0.519 \\
\hline Average oDesk Test Score (0/1) & 0.500 & 0.494 & 0.495 & 0.496 \\
\hline Number of oDesk Tests $(0 / 1)$ & 0.409 & 0.418 & 0.411 & 0.421 \\
\hline \multirow[t]{3}{*}{ Wage Bid } & 8.676 & 7.680 & 8.191 & 7.613 \\
\hline & $(12.152)$ & (11.745) & $(12.129)$ & (11.538) \\
\hline & 5.56 & 5 & 5.56 & 5 \\
\hline \multirow[t]{3}{*}{ Fixed Price Bid } & 10.225 & 9.480 & 9.943 & 9.379 \\
\hline & (13.296) & (14.175) & $(12.692)$ & $(15.269)$ \\
\hline & 8 & 7 & 7.78 & 6.67 \\
\hline \multirow[t]{3}{*}{ Profile Wage } & 6.397 & 5.926 & 6.150 & 5.924 \\
\hline & $(11.158)$ & (10.828) & $(10.602)$ & (11.237) \\
\hline & 4 & 3.15 & 4 & 3.15 \\
\hline Profile Picture (0/1) & 0.828 & 0.845 & 0.835 & 0.848 \\
\hline Agency Membership (0/1) & 0.253 & 0.241 & 0.25 & 0.237 \\
\hline Employer Initiated Application (0/1) & 0.038 & 0.031 & 0.035 & 0.030 \\
\hline \multirow[t]{3}{*}{ oDesk Rating Score } & 3.236 & 3.226 & 3.235 & 3.221 \\
\hline & $(2.205)$ & $(2.208)$ & $(2.204)$ & $(2.210)$ \\
\hline & 4.8 & 4.8 & 4.8 & 4.774 \\
\hline No rating Score $(0 / 1)$ & 0.709 & 0.707 & 0.709 & 0.705 \\
\hline Previously Hired by Employer (0/1) & 0.000 & 0.004 & 0.001 & 0.005 \\
\hline Interviewed (0/1) & 0.137 & 0.108 & 0.125 & 0.104 \\
\hline Short Listed (0/1) & 0.060 & 0.035 & 0.052 & 0.029 \\
\hline \multirow[t]{3}{*}{ Fraction of Cover Letter that is Original } & 0.289 & 0.285 & 0.283 & 0.289 \\
\hline & $(0.337)$ & $(0.335)$ & $(0.335)$ & $(0.336)$ \\
\hline & 0.125 & 0.125 & 0.125 & 0.128 \\
\hline Number of Observations & 87,274 & 269,206 & 185,432 & 171,048 \\
\hline
\end{tabular}


Table A4: LDC Status and oDesk Experience Control Coefficients

\begin{tabular}{|c|c|c|c|c|}
\hline & \multicolumn{2}{|c|}{ (1) } & \multicolumn{2}{|c|}{ (2) } \\
\hline Model & \multicolumn{2}{|c|}{ Logit } & \multicolumn{2}{|c|}{ Conditional Logit } \\
\hline Outcome & \multirow{2}{*}{\multicolumn{2}{|c|}{$\begin{array}{c}\text { Applicant success } \\
0.035\end{array}$}} & \multicolumn{2}{|c|}{ Applicant success } \\
\hline Overall Mean & & & \multicolumn{2}{|c|}{0.035} \\
\hline Mean for DC contractors & \multicolumn{2}{|c|}{0.084} & 0.0 & \\
\hline & Raw est. & Ddds ratios & Raw est. & Odds ratio \\
\hline LDC & $\begin{array}{c}-0.580 * * * \\
(0.0253)\end{array}$ & 0.560 & $\begin{array}{c}-0.518^{* * * *} \\
(0.0264)\end{array}$ & 0.596 \\
\hline Platform Experience & $\begin{array}{l}0.450 * * * \\
(0.0255)\end{array}$ & 1.569 & $\begin{array}{l}0.464 * * * \\
(0.0268)\end{array}$ & 1.590 \\
\hline Off Platform Work Experience (0/1) & $\begin{array}{l}-0.0119 \\
(0.0220)\end{array}$ & 0.988 & $\begin{array}{c}0.0758^{* * * *} \\
(0.0234)\end{array}$ & 1.079 \\
\hline Fraction of Cover Letter that is Original & $\begin{array}{l}0.810 * * * \\
(0.0281)\end{array}$ & 2.248 & $\begin{array}{l}0.734 * * * \\
(0.0302)\end{array}$ & 2.084 \\
\hline Profile Picture & $\begin{array}{l}0.214 * * * \\
(0.0285)\end{array}$ & 1.238 & $\begin{array}{l}0.284 * * * \\
(0.0298)\end{array}$ & 1.328 \\
\hline oDesk Rating Score & $\begin{array}{l}0.128 * * * \\
(0.0150)\end{array}$ & 1.137 & $\begin{array}{l}0.145^{* * * *} \\
(0.0155)\end{array}$ & 1.156 \\
\hline No oDesk rating Score & $\begin{array}{l}-0.0856 \\
(0.0777)\end{array}$ & 0.918 & $\begin{array}{c}-0.235^{* * *} \\
(0.0797)\end{array}$ & 0.790 \\
\hline Log(Wage Bid $)$ & $\begin{array}{l}0.323 * * * \\
(0.0151)\end{array}$ & 1.382 & $\begin{array}{l}-0.0350^{*} \\
(0.0194)\end{array}$ & 0.966 \\
\hline Average oDesk Test Score & $\begin{array}{l}0.225 * * * \\
(0.0199)\end{array}$ & 1.252 & $\begin{array}{l}0.262 * * * \\
(0.0212)\end{array}$ & 1.299 \\
\hline Number of oDesk Test Scores & $\begin{array}{c}0.0672 * * * \\
(0.0204)\end{array}$ & 1.069 & $\begin{array}{c}0.0999 * * * \\
(0.0217)\end{array}$ & 1.105 \\
\hline Agency Member & $\begin{array}{c}-0.270^{* * * *} \\
(0.0256)\end{array}$ & 0.763 & $\begin{array}{c}-0.240^{* * * *} \\
(0.0283)\end{array}$ & 0.787 \\
\hline Education & $\begin{array}{c}-0.0595 * * * \\
(0.00915)\end{array}$ & 0.942 & $\begin{array}{c}-0.0462 * * * \\
(0.00947)\end{array}$ & 0.955 \\
\hline Current Offline Employment Status & $\begin{array}{l}-0.0325 \\
(0.0208)\end{array}$ & 0.968 & $\begin{array}{c}-0.0648 * * * \\
(0.0219)\end{array}$ & 0.937 \\
\hline Employer Initiated Application & $\begin{array}{l}1.203 * * * \\
(0.0379)\end{array}$ & 3.331 & $\begin{array}{l}1.709 * * * \\
(0.0555)\end{array}$ & 5.521 \\
\hline Prior Hire & $\begin{array}{l}2.340 * * * \\
(0.0742)\end{array}$ & 10.38 & $\begin{array}{l}2.183 * * * \\
(0.0911)\end{array}$ & 8.872 \\
\hline Constant & $\begin{array}{c}-4.755 * * * \\
(0.0634)\end{array}$ & 0.00861 & & \\
\hline Observations & 356 & & 356 & \\
\hline Chi test & & & 50 & \\
\hline Number of groups/cases & 12 & & 12,5 & \\
\hline
\end{tabular}

Sample is restricted to jobs posted by employers from DCs and jobs for which one contractor was hired. Robust standard errors are reported in parentheses. $* p<0.10 * * p<0.05 * * * p<0.01$. 
Table A5: Differential Impact of Platform Specific Experience for LDC Contractors on Interviews \& on being Short Listed

\begin{tabular}{|c|c|c|c|c|}
\hline \multirow{2}{*}{$\begin{array}{r}\text { Outcome } \\
\text { Overall Mean } \\
\text { Mean for DC contractors with } \\
\text { low oDesk experience }\end{array}$} & \multicolumn{2}{|c|}{$\begin{array}{c}\text { Interviewed } \\
0.034 \\
0.063\end{array}$} & \multicolumn{2}{|c|}{$\begin{array}{c}\text { Short Listed } \\
0.027 \\
0.05\end{array}$} \\
\hline & Raw est. & Odds ratio & Raw est. & Odds ratio \\
\hline LDC & $\begin{array}{c}-0.562 * * * \\
(0.0317)\end{array}$ & 0.570 & $\begin{array}{c}-0.499 * * * \\
(0.0480)\end{array}$ & 0.607 \\
\hline Platform Experience & $\begin{array}{c}0.134 * * * \\
(0.0396)\end{array}$ & 1.143 & $\begin{array}{c}0.329 * * * \\
(0.0550)\end{array}$ & 1.389 \\
\hline LDC X Platform Experience & $\begin{array}{c}0.305 * * * \\
(0.0418)\end{array}$ & 1.357 & $\begin{array}{c}0.205^{* * *} \\
(0.0584)\end{array}$ & 1.228 \\
\hline Controls & $Y$ & & & \\
\hline Job FE & $x$ & & & 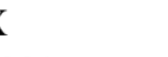 \\
\hline Observations & 304 & 768 & & 201 \\
\hline Chi test & 50 & & & 39 \\
\hline Number of groups/cases & 10,4 & & & \\
\hline
\end{tabular}

The specification is the same as in column 3 of Table 4, with two different outcome variables: being interviewed, and being short-listed. 
Table A6: Differential Impact of Platform Specific Experience for LDC Contractors with Full Sample

\begin{tabular}{|c|c|c|}
\hline Outcome & \multicolumn{2}{|c|}{ Applicant success } \\
\hline Overall Mean & \multicolumn{2}{|c|}{0.046} \\
\hline Mean for DC contractors & \multicolumn{2}{|c|}{0.067} \\
\hline & Raw est. & dds ratio \\
\hline LDC & $\begin{array}{c}-0.672 * * * \\
(0.0288)\end{array}$ & 0.511 \\
\hline Platform Experience & $0.177 * * *$ & 1.193 \\
\hline & $(0.0342)$ & \\
\hline LDC X Platform & $0.290 * * *$ & 1.337 \\
\hline Experience & $(0.0363)$ & \\
\hline Controls & & \\
\hline Job FE & $Y$ & \\
\hline Observations & 563 & \\
\hline Chi test & 51 & \\
\hline Number of groups/cases & 17,0 & \\
\hline
\end{tabular}

Results are from a conditional logit regression. Sample is restricted to jobs posted by employers from DCs. Robust standard errors are reported in parentheses.

$* p<0.10 * * p<0.05 * * * p<0.01$. 
Table A7: Excluding Applicants Previously Hired by Employer \& Employer Initiated applicants

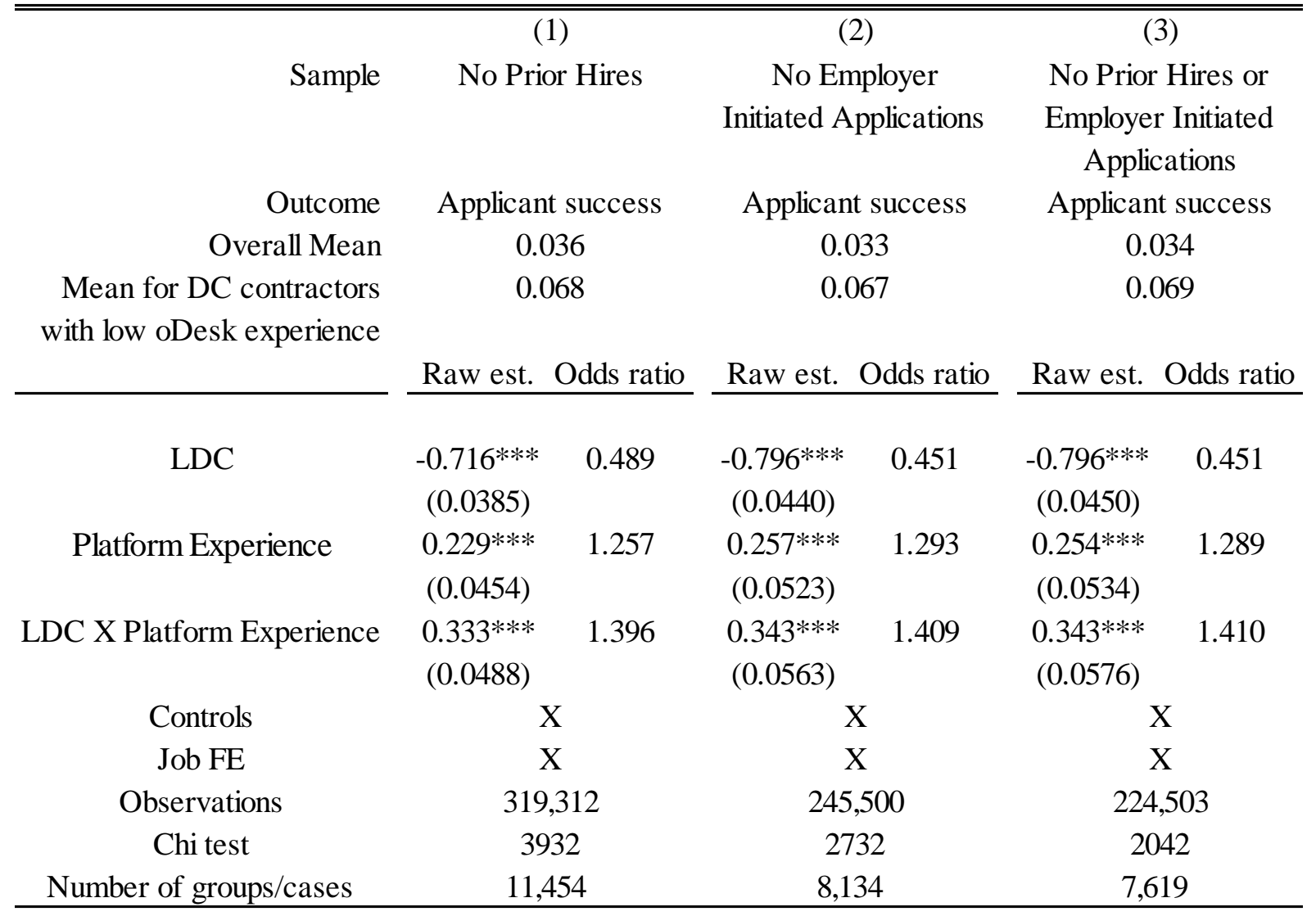

Results are from conditional logit regressions. Sample is restricted to jobs posted by employers from DCs and jobs for which one contractor was hired. Robust standard errors are reported in parentheses.

$* p<0.10 * * p<0.05 * * * p<0.01$. 
Table A8: Robustness to Contractor oDesk Experience Measure

\begin{tabular}{|c|c|c|c|c|c|c|}
\hline \multirow{6}{*}{$\begin{array}{r}\text { Sample } \\
\text { Outcome } \\
\text { Overall Mean } \\
\text { Mean for DC contractors } \\
\text { with low oDesk experience }\end{array}$} & \multicolumn{2}{|c|}{ (1) } & \multicolumn{2}{|c|}{ (2) } & \multicolumn{2}{|c|}{ (3) } \\
\hline & \multicolumn{2}{|c|}{ Full Sample } & \multicolumn{2}{|c|}{$\begin{array}{l}\text { Employers with } 0 \\
\text { Prior Hires }\end{array}$} & \multicolumn{2}{|c|}{$\begin{array}{c}\text { Employers with }>0 \\
\text { Prior Hires }\end{array}$} \\
\hline & \multicolumn{2}{|c|}{ Applicant success } & \multicolumn{2}{|c|}{ Applicant success } & \multicolumn{2}{|c|}{ Applicant success } \\
\hline & \multicolumn{2}{|c|}{0.035} & \multicolumn{2}{|c|}{0.043} & \multicolumn{2}{|c|}{0.033} \\
\hline & \multicolumn{2}{|c|}{0.097} & \multicolumn{2}{|c|}{0.112} & \multicolumn{2}{|c|}{0.092} \\
\hline & Raw est. & dds ratio & Raw est. & dds ratio & Raw est. & dds ratio \\
\hline LDC & $\begin{array}{c}-0.834 * * * \\
(0.0529)\end{array}$ & 0.434 & $\begin{array}{l}-0.697 * * * \\
(0.0978)\end{array}$ & 0.498 & $\begin{array}{l}-0.894 * * * \\
(0.0629)\end{array}$ & 0.409 \\
\hline $\begin{array}{l}\text { Platform Experience in 2nd } \\
\text { Quintile }\end{array}$ & $\begin{array}{l}0.321 * * * \\
(0.0736)\end{array}$ & 1.378 & $\begin{array}{c}0.437 * * * \\
(0.134)\end{array}$ & 1.549 & $\begin{array}{l}0.269 * * * \\
(0.0881)\end{array}$ & 1.309 \\
\hline $\begin{array}{c}\text { Platform Experience in 3rd } \\
\text { Quintile }\end{array}$ & $\begin{array}{l}0.399 * * * \\
(0.0719)\end{array}$ & 1.491 & $\begin{array}{c}0.573 * * * \\
(0.132)\end{array}$ & 1.773 & $\begin{array}{l}0.325 * * * \\
(0.0856)\end{array}$ & 1.384 \\
\hline $\begin{array}{c}\text { Platform Experience in 4th } \\
\text { Quintile }\end{array}$ & $\begin{array}{l}0.519 * * * \\
(0.0720)\end{array}$ & 1.680 & $\begin{array}{l}0.689 * * * \\
(0.134)\end{array}$ & 1.992 & $\begin{array}{l}0.445^{* * * *} \\
(0.0854)\end{array}$ & 1.560 \\
\hline $\begin{array}{l}\text { Platform Experience in 5th } \\
\text { Quintile }\end{array}$ & $\begin{array}{l}0.692 * * * \\
(0.0737)\end{array}$ & 1.997 & $\begin{array}{c}0.860 * * * \\
(0.135)\end{array}$ & 2.362 & $\begin{array}{l}0.621 * * * \\
(0.0879)\end{array}$ & 1.860 \\
\hline $\begin{array}{l}\text { LDC*Platform Experience } \\
\text { in 2nd Quintile }\end{array}$ & $\begin{array}{c}0.0844 \\
(0.0807)\end{array}$ & 1.088 & $\begin{array}{l}-0.108 \\
(0.148)\end{array}$ & 0.898 & $\begin{array}{c}0.166 * \\
(0.0963)\end{array}$ & 1.181 \\
\hline $\begin{array}{l}\text { LDC*Platform Experience } \\
\text { in 3rd Quintile }\end{array}$ & $\begin{array}{l}0.290 * * * \\
(0.0710)\end{array}$ & 1.337 & $\begin{array}{l}0.0950 \\
(0.130)\end{array}$ & 1.100 & $\begin{array}{l}0.375^{* * * *} \\
(0.0849)\end{array}$ & 1.455 \\
\hline $\begin{array}{l}\text { LDC*Platform Experience } \\
\text { in 4th Quintile }\end{array}$ & $\begin{array}{l}0.432 * * * \\
(0.0663)\end{array}$ & 1.540 & $\begin{array}{l}0.237 * \\
(0.123)\end{array}$ & 1.268 & $\begin{array}{l}0.516 * * * \\
(0.0788)\end{array}$ & 1.675 \\
\hline $\begin{array}{l}\text { LDC*Platform Experience } \\
\text { in 5th Quintile }\end{array}$ & $\begin{array}{c}0.500 * * * \\
(0.0673)\end{array}$ & 1.648 & $\begin{array}{l}0.290 * * \\
(0.123)\end{array}$ & 1.336 & $\begin{array}{l}0.590 * * * \\
(0.0804)\end{array}$ & 1.804 \\
\hline Controls & 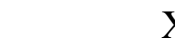 & & $X$ & & $X$ & \\
\hline Job FE & $Y$ & & $x$ & & $X$ & \\
\hline Observations & 326 & & 87,2 & & 269 , & \\
\hline Chi test & 5,3 & & 14 & & 39 & \\
\hline Number of groups/cases & 12,5 & & 3,7 & & 8,7 & \\
\hline
\end{tabular}

Results are from conditional logit regressions. Sample is restricted to jobs posted by employers from DCs and jobs for which one contractor was hired. Robust standard errors are reported in parentheses.

$* p<0.10 * * p<0.05 * * * p<0.01$. 